九州大学学術情報リポジトリ

Kyushu University Institutional Repository

\title{
Geological and Prtrological Studies of the "Shirasu" in South Kyushu, Japan Parts IV-VII
}

Taneda, Sadakatu

Faculty of Science, Kyushu University

Miyachi, Mutsumi

Department of General Education, Kyushu University

Morita, Jun-nosuke

Irisa, Sumiharu

https://doi.org/10.5109/1543911

出版情報：九州大學理學部紀要：Series D, Geology. 20 (1)，pp.147-176，1970-01-25. Faculty of Science, Kyushu University バージョン:

権利関係 : 
Mem. Fac. Sci., Kyushu Univ., Ser. D, Geology, Vol. XX, No. 1, pp. 147-175, text-figs. 1-19, tables. 1-16. Jan. 25, 1970

\title{
Geological and Petrological Studies of the "Shirasu" in South Kyushu, Japan
}

\author{
Parts IV-VII
}

By

\author{
Sadakatu TANEDA, Mutsumi MIYACHI, Jun-nosuke MORITA \\ and Sumiharu IRISA
}

\begin{abstract}
The geology, and lithological and petrographical properties of the "Shirasu" of south Kyushu are described. The refractive indices of the "Shirasu glass" are 1.496 1.503, while those of the "Aso-" and "Ata pyroclastic flows" 1.505 1.515. The "median diameters (Md)" obtained by mechanical analyses are $0.18 \sim 0.32 \mathrm{~mm}$. As regards the maximum value of $\mathrm{Md}$, however, there is a tendency that it is higher around Kagoshima City, decreasing in every direction towards the outside. It seems to be true that the "Shirasu" proper is one of the pumice flow deposits ejected from the Aira caldera volcano.
\end{abstract}

\section{Introduction}

In his previous papers (Part I, 1954; Part II, 1957), TANEDA gave the geological and petrological outline of the "Shirasu", the wide-spread loose tufaceous deposits forming a vast table land in south Kyushu, and infered that the "Shirasu" proper is a deposit formed by a succession of abnormal explosions of the pumice flow type. And then in other papers (Part III, TANEDA et al., 1957, etc.) the geology, and lithological and petrographical properties of the "Shirasu" in the Tsuruda-Hiwaki-Kôriyama area are described. The contents of these previous publications are as follows:

Part I Preliminary note (S. TANedA, Vol. IV, No. 2, 1954) General description of the "Shirasu" and "Hai-ishi", microphotograph, mechanical analysis.

Part II Preliminary note (2) (S. TANEDA, Vol. VI, No. 2, 1957) Shape of component fragments and particles (microphotograph and electron micrograph), structure and texture, size distribution, carbonized plants, high temperature experiment and load-bearing test, "Artificial Shirasu", differential thermal analyses of decomposed "Shirasu".

Part III The "Shirasu" in the Tsuruda-Hiwaki-Kôriyama area (S. TANEDA, S. MiYachi and M. Nishihara, Vol. VI, No. 2, 1957) Geological

$\overline{\text { Manuscript received August }}$ 4, 1969. 
occurrence, structure and texture, size distribution, proportion of component minerals.

In this paper is given the description on the "Shirasu" in the Takaharu area (Part IV), the Hitoyoshi area (Part V), the southwestern part of the Satsuma Peninsula (Part VI) and the south ôsumi district (Part VII).

This work has been done on the Grant in Aid for Scientific Researches from the Ministry of Education, Japan.

\section{Part IV. The "Shirasu" in the Takaharu Area, Miyazaki Prefecture}

(Sadakatu TANEDA and Mutsumi MIYACHI)

\section{Outline of geology and petrography}

The outline of geology of the Takaharu area is shown in Table 1 and Fig. 1. The brief descriptions on the seven main geologic units in this area are given below.

Table 1. General stratigraphic succession.

\begin{tabular}{|c|c|c|}
\hline Age & $\begin{array}{c}\text { Kokubu area } \\
\text { (SAWAMURA, 1956) }\end{array}$ & $\begin{array}{l}\text { Takaharu area } \\
\text { (TANEDA \& MIYACHI, 1968) }\end{array}$ \\
\hline \multirow[t]{2}{*}{ Alluvium } & \multirow{2}{*}{$\begin{array}{l}\text { Alluvium (gravel, sand, and clay) } \\
\text { Ash and pumice bed } \\
\text { Pumiceous gravel and sand bed }\end{array}$} & $\begin{array}{l}\text { Alluvial deposit } \\
\text { Newer Kirishima volcanics }\end{array}$ \\
\hline & & \multirow{2}{*}{ "Secondary Shirasu" } \\
\hline \multirow{8}{*}{ Pleistocene } & \multirow{3}{*}{ Ito pumice flow $\left\{\begin{array}{l}\text { pumice tuff } \\
\text { breccia } \\
\text { welded tuff }\end{array}\right.$} & \\
\hline & & Older Kirishima volcanics \\
\hline & & \multirow[t]{4}{*}{ Hai-ishi II welded tuff } \\
\hline & Iwato pumice flow & \\
\hline & Shigehisa pumice flow & \\
\hline & Shinkawa pumice flow & \\
\hline & Haginomoto pumice flow & Hai-ishi I welded tuff \\
\hline & Kokubu group & \\
\hline Pliocene & Tertiary andesite & \\
\hline Mesozoic & Shimanto group & Shimanto group \\
\hline
\end{tabular}

(1) The lowest unit is the "Shimanto group" regarded as the Mesozoic age, consisting of sandstone and shale. It is distributed in the eastern part of the area.

(2) The Hai-ishi I is welded tuff found only at the south of the Hyûga- 


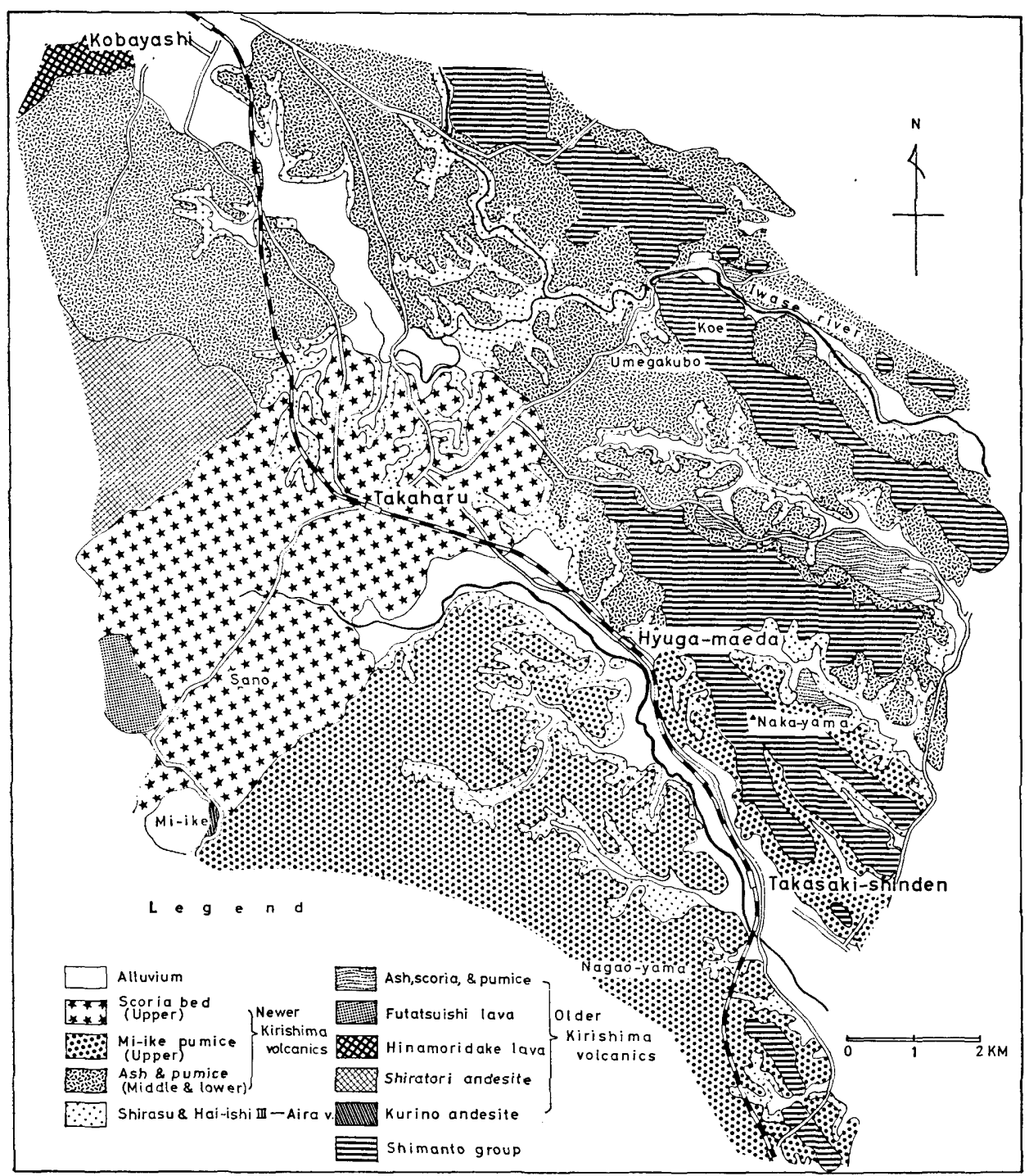

Fig. 1. Geological Map of the Takaharu Area.

maeda Station, Takasaki Town. As its base is nowhere exposed, the thickness is not known yet. It is white or greyish white welded tuff studded with some pumice fragments and a large amount of lithic ones, most of which are andesite, subrounded or subangular in shape, and 5 to $6 \mathrm{~cm}$ (rarely up to $20 \mathrm{~cm}$ ) in diameter. The phenocrysts of andesine and hypersthene are extremely rarely found in the groundmass which consists mainly of colorless glass fragments and accessory minerals, which are magnetite, ilmenite, and zircon. In Table 2 the optical constants for the constituent minerals of the Hai-ishi $\mathrm{I}$ is shown.

The Hai-ishi I may be correlated with the SAWAMURA's Haginomoto welded tuff in the Kokubu area, Kagoshima Prefecture, on the basis of similar petrographical character of the constituent minerals. As to the eruptive source of 


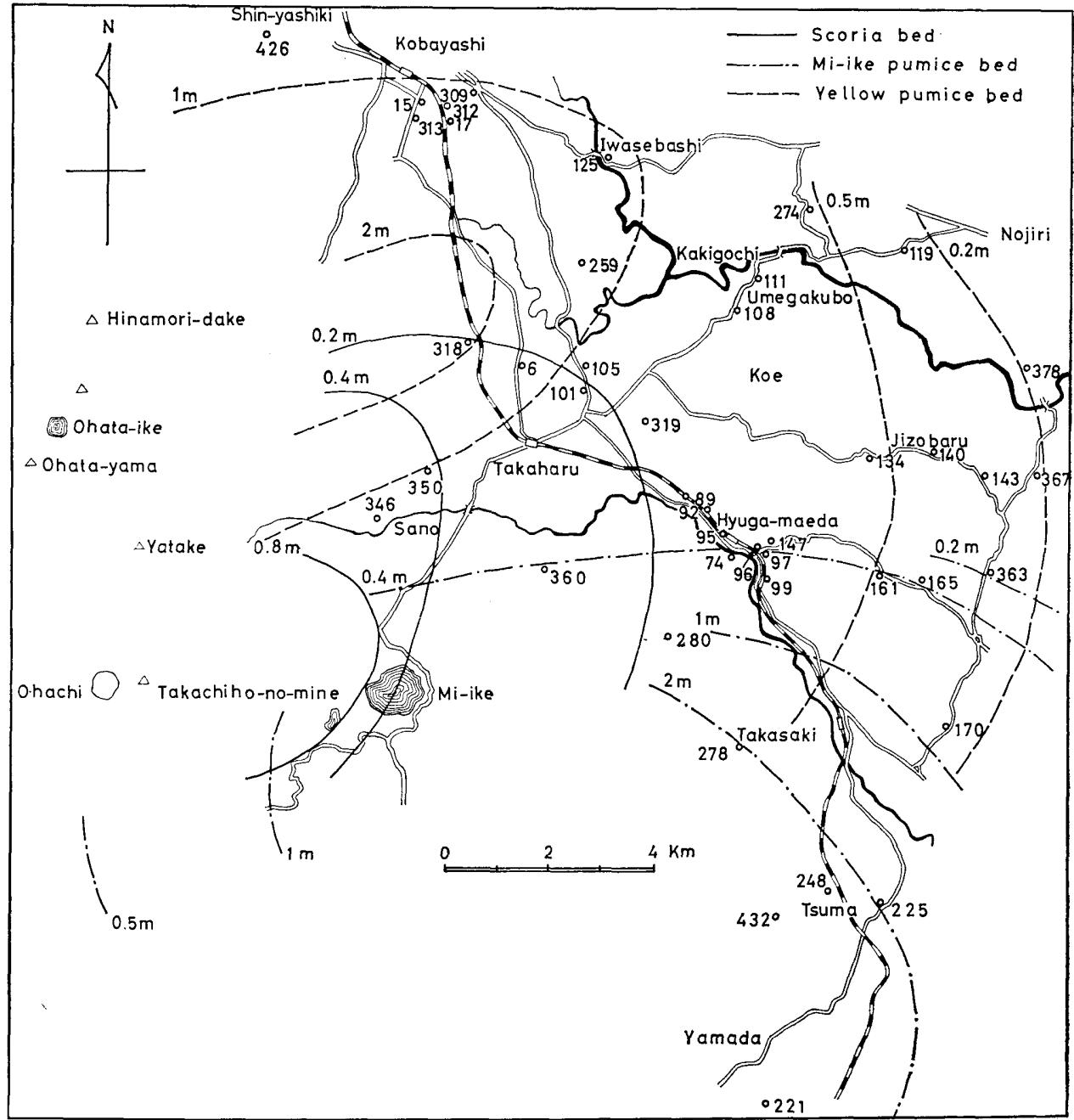

Fig. 2. Sampling map of the "Shirasu" and isopack map of the pumice beds and the scoria bed of the Newer Kirishima volcanics.

the Hai-ishi I welded tuff, SAwAmura (1956) thought that it had been derived from the Ata caldera volcano, but it is rather considerable to be correlated to the TANEDA's older Kirishima pumice flow (1963) which may belong to the Kakutô caldera volcano.

(3) The Hai-ishi II welded tuff is found at the roadcut cliff in south of the Hyûga-maeda Station. It spreads over the adjacent wide area to the north and northwest (Kobayashi City and Ebino Town). The most general appearance of the Hai-ishi II is plagioclase-andesitic, grey to dark bluish grey, considerably hard and compact. At Yamanokuchibaru, north of Kobayashi City and at Kokan, Ebino Town the maximum thickness of the welded tuff is about 20 meters, the lowermost part up to $5 \mathrm{~m}$ being non-welded. The Hai-ishi II is unconformably overlain by the pyroclastic falls ejected from the Older Kirishima volcano. The relation between the Hai-ishi II welded tuff and the Older Kirishima andesites 
Part IV. The "Shirasu" in the Takaharu Area, Miyazaki Prefecture

Table 2. Optical constant of the constituent minerals for the Hai-ishi welded tuffs and the "Shirasu".

\begin{tabular}{|c|c|c|c|c|c|c|}
\hline \multirow{2}{*}{ Rock name } & \multirow{2}{*}{ No. } & \multicolumn{2}{|c|}{ Plagioclase } & \multicolumn{2}{|c|}{ Hypersthene } & \multirow{2}{*}{$\begin{array}{c}\text { Glass } \\
\mathrm{n}_{\max }\end{array}$} \\
\hline & & $\mathrm{n}_{1 \max }$ & $\mathrm{n}_{2 \max }$ & $\alpha_{\min }$ & $\gamma \max$. & \\
\hline \multirow{2}{*}{ Hai-ishi I } & 74 & 1.546 & 1.554 & 1.704 & 1.717 & $1.514^{*}$ \\
\hline & 99 & 1.546 & 1.554 & 1. 702 & 1.721 & $1.514^{*}$ \\
\hline \multirow{3}{*}{ Hai-ishi II } & 98 & 1.548 & 1.558 & 1. 704 & 1.722 & $1.497 \sim 1.500$ \\
\hline & 543 & 1.547 & 1.560 & 1.704 & 1.720 & $* *$ \\
\hline & 585 & 1.545 & 1.555 & 1.705 & 1.722 & $* *$ \\
\hline \multirow{2}{*}{ Hai-ishi III } & 111 & 1.549 & 1.556 & 1.707 & 1.728 & 1.497 \\
\hline & 125 & 1.549 & 1.556 & 1.706 & 1.727 & 1.496 \\
\hline \multirow{6}{*}{ "Shirasu" } & 90 & 1.549 & 1.556 & 1.710 & 1.729 & 1.499 \\
\hline & 96 & 1.549 & 1.556 & 1.170 & 1.729 & 1. 496 \\
\hline & 101 & 1.548 & 1.556 & 1.705 & 1.726 & 1.500 \\
\hline & 105 & 1.548 & 1.556 & 1.706 & 1.726 & 1.500 \\
\hline & 165 & 1.546 & 1.558 & 1.705 & 1.727 & 1.500 \\
\hline & 221 & 1.547 & 1.556 & 1.707 & 1.725 & 1.500 \\
\hline
\end{tabular}

* Glass is altered by weatheing.

** Glass is suffered by devitrification.

is not clearly known yet.

Under the microscope it shows a porphyritic texture, with a large amount of plagioclase phenocrysts which are mostly fragmentary and rarely euhedral in shape. The plagioclase shows zonal structures sometimes. A less amount of microphenocrysts of hypersthene and augite are also met with. Groundmass consists mainly of light brown glass with accessory magnetite, ilmenite, and zircon. The optical constants for the constituent minerals are shown in Table 2.

The Hai-ishi II welded tuff may be correlated with the welded tuff which forms the base of the Jyûsantsukahai Plateau in the northern part of Kajiki Town, Kagoshima Prefecture.

(4) The "Older Kirishima volcanics" consist of many lavas and pyroclastics, distributed in the north- and southeastern parts of the Kirishima National Park. The lavas are olivine-bearing pyroxene andesite belonging to the Kurino andesite group, the younger and the older pyroxene andesites of the Shiratori andesite group, and the Futatsuishi olivine $( \pm)$-pyroxene andesite and the Hinamoridake olivine basalt and olivine pyroxene andesite of the Older Takachiho group.

The Hinamoridake lava is covered directly by the "Older Kirishima pyroclastic falls". The Kurino andesite is covered by the "Shirasu". But it is not clear whether the Shiratori and Futatsuishi andesites are covered by the "Older Kirishima pyroclastics" or by the "Shirasu".

The pyroclastics, 12 to 15 meters in thickness, consist of fifteen or sixteen beds of pumice, ash, and scoria fall deposits, at Shin-yashiki, Kobayashi City and Umegakubo, Takaharu Town. In Table 3 the stratigraphic section of the pyroclastics at Umegakubo is shown. 
Table 3. Thickness of the pyroclastic deposits at Umegakubo, Takaharu Town, Miyazaki Prefecture.

\begin{tabular}{l|l|r}
\hline No. & \multicolumn{1}{|c}{ Products } & Thickness \\
\hline & Newer Kirishima volcanic ejecta & $500 \mathrm{~cm}$ \\
& "Shirasu" (pale orange) & $200 \mathrm{~cm}$ \\
& Hai-ishi III welded tuff (grey) & $1000 \mathrm{~cm}$ \\
\hline $111-\mathrm{L}$ & Black very coarse ash* & $60 \mathrm{~cm}$ \\
$111-\mathrm{K}$ & Reddish brown coarse ash & $60 \mathrm{~cm}$ \\
$111-\mathrm{J}$ & Grey pumice lapilli & $15 \mathrm{~cm}$ \\
$111-\mathrm{I}$ & Yellow coarse ash* & $60 \mathrm{~cm}$ \\
$111-\mathrm{H}$ & Brown scoria & $20 \mathrm{~cm}$ \\
$111-\mathrm{G}$ & Reddish brown scoria & $80 \mathrm{~cm}$ \\
$111-\mathrm{F}$ & Yellowish brown ash with andesitic fragments & $10 \mathrm{~cm}$ \\
$111-\mathrm{E}$ & Reddish brown scoria & $15 \mathrm{~cm}$ \\
$111-\mathrm{D}$ & Dark brown medium ash* & $15 \mathrm{~cm}$ \\
$111-\mathrm{C}$ & Brown coarse ash & $30 \mathrm{~cm}$ \\
$111-\mathrm{B}$ & Yellowish brown very coarse ash & $10 \mathrm{~cm}$ \\
$111-\mathrm{A}$ & Brown scoria & $100 \mathrm{~cm}$ \\
\hline & Unknown Mesozoic formation & \\
\hline
\end{tabular}

* Samples were analysed mechanically.

(5) The Hai-ishi III welded tuff crops out mainly along the banks of the Iwase river. It is white to grey, 10 to 15 meters thick, and contains many flatted pumice fragments, which are usually $20 \mathrm{~cm}$, and rarely up to $100 \mathrm{~cm}$ in diameter at Umegakubo. Accidental fragments of andesite and shale are much less than pumice fragment. It contains phenocrystic plagioclase, quartz, and hypersthene. Plagioclase is 0.5 to $1 \mathrm{~mm}$ in size, and subhedral and flaky in shape. The outline of quartz crystals is irregularly embayed by corrosion. Hypersthene is 0.2 to $0.8 \mathrm{~mm}$ in length, showing strong pleocroism. Augite is very rare. The groundmass is composed of pale yellowish brown glass with minute grains of iron ore, showing welding texture. Their optical constants are shown in Table 2.

$(5$ ') The "Shirasu" is a nonwelded pumice flow deposit belonging to the Aira caldera volcano. It is approximately 10 meters in thickness. It is a light grey, not consolidated, and composed mainly of pumice fragments, glass flakes, lithic fragments, and a small amount of crystal grains, which are plagioclase, quartz, hypersthene, augite, and a less amount of magnetite, ilmenite, apatite, and zircon. The plagioclase is 0.5 to $2 \mathrm{~mm}$ in length, and euhedral to subhedral in form. Quartz is rarely found, which is 0.5 to $1 \mathrm{~mm}$ in diameter, showing a shape of the high form. Hypersthene is 0.2 to $2 \mathrm{~mm}$ in length, showing strong pleochroism. Augite is very rare. The optical constants for plagioclase, hypersthene and glass are shown in Table 2. Pumice fragments are 2 to $20 \mathrm{~cm}$ in diameter and generally subrounded to subangular. Lithic fragments are 2 to $3 \mathrm{~cm}$ in diameter which are pyroxene- and hornblende-andesites, shale and sandstone presumably from the Mesozoic sediments, and the older welded tuff. 
Part IV. The "Shirasu" in the Takaharu Area, Miyazaki Prefecture

Table 4. Deposits of the Newer Kirishima pyroclastics at Sano, Takaharu Town, Miyazaki Prefecture

\begin{tabular}{l|l|c}
\hline \multicolumn{1}{|c|}{ Products } & Thickness \\
\hline \multirow{5}{*}{ Upper } & scoria* (c) & $50 \mathrm{~cm}$ \\
\cline { 2 - 3 } & Black loam & 25 \\
& Black loam & 35 \\
& Black loam with yellow pumice lapilli & 90 \\
& Yellowish brown loam with yellow pumice lapilli & 35 \\
& Yellowish brown loam & 25 \\
& Yellowish dark brown loam & 50 \\
& Yellowish brown loam & 13 \\
\cline { 2 - 3 } & Mi-iké pumice bed (yellow pumice lalilli)* (b) & \\
& Yellow fine ash & 80 \\
\cline { 2 - 3 } Middle & Bluish grey fine ash & 85 \\
& Dark brown loam with yellow pumice lapilli & 55 \\
& Black loam & 15 \\
& Yellow loam & 25 \\
& Dark brown loam & 16 \\
& Purplish brown loam & 40 \\
\hline \multirow{5}{*}{ Lower } & Yellowish brown loam & 100 \\
\cline { 2 - 3 } & Alternating layers of yellow pumice lapilli & \\
\cline { 2 - 3 } & and grey coarse ash* (a) & \\
\hline
\end{tabular}

The "Shirasu" and Hai-ishi III are correlated with the SAwamura's Ito pumic flow deposit (1956).

(6) The "Secondary Shirasu" is the sedimentary bed derived from the "Shirasu" proper, being usually well-laminated, sometimes cross-laminated. It covers unconformably the "Shirasu", accompanied with gravel, sand, and clay.

(7) Newer Kirishima volcanics consist of lavas and pyroclastics which are distributed in the eastern surroundings of the Kirishima volcano. The lavas are Nakadaké lava (olivine-pyroxene andesite, and pyroxene andesite), Takachiho-nominé lava (olivine-pyroxene andesite), Shinmoe-daké lava (olivine-pyroxene andesite), and Ohachi lava (olivine-pyroxene andesite), all of which are of the later stage than the Aira volcanism. The pyroclastics, 2 to 8 meters in thickness, involve the pumice, ash, loam, and scoria fall beds. In Table 4 the stratigraphic succession of the pyroclastics at Sano is shown. The Mi-iké pumice bed is not found in this place but the top of Mt. Nagaoyama. The eruption vents of the three beds (a), (b), and (c) marked by an asterisk in Table 4 are Ohata lake, Mi-iké lake and Mt. Ohachi, respectively.

\section{Size distribution}

The "Shirasu" pumice flow deposit, and some of ash and pumice fall deposits were mechanically analysed, excluding large fragments exceeding $4 \mathrm{~mm}$ in dia- 


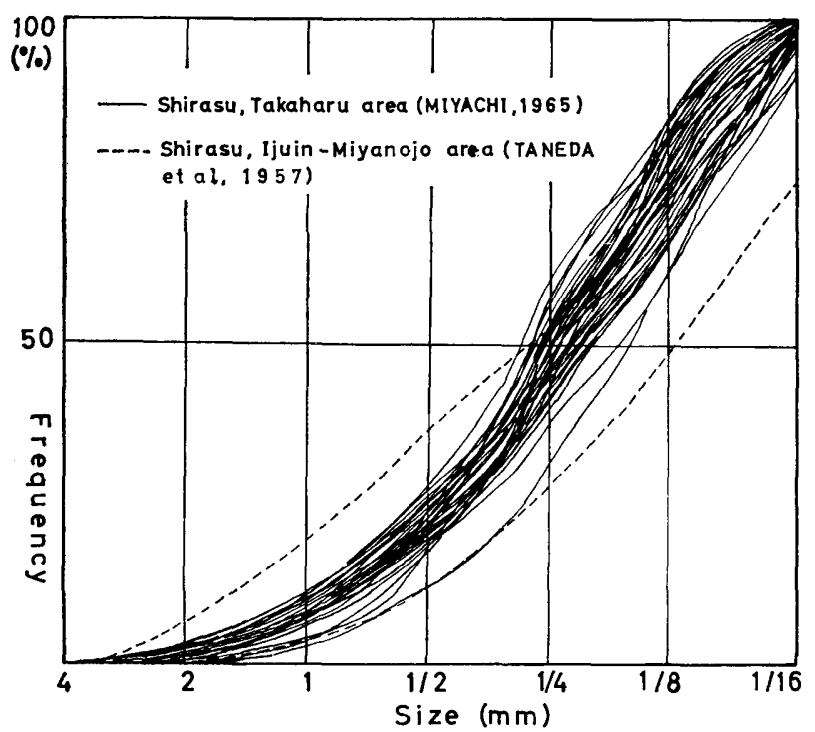

Fig. 3. Cumulative curves for the "Shirasu" in the Takaharu area.

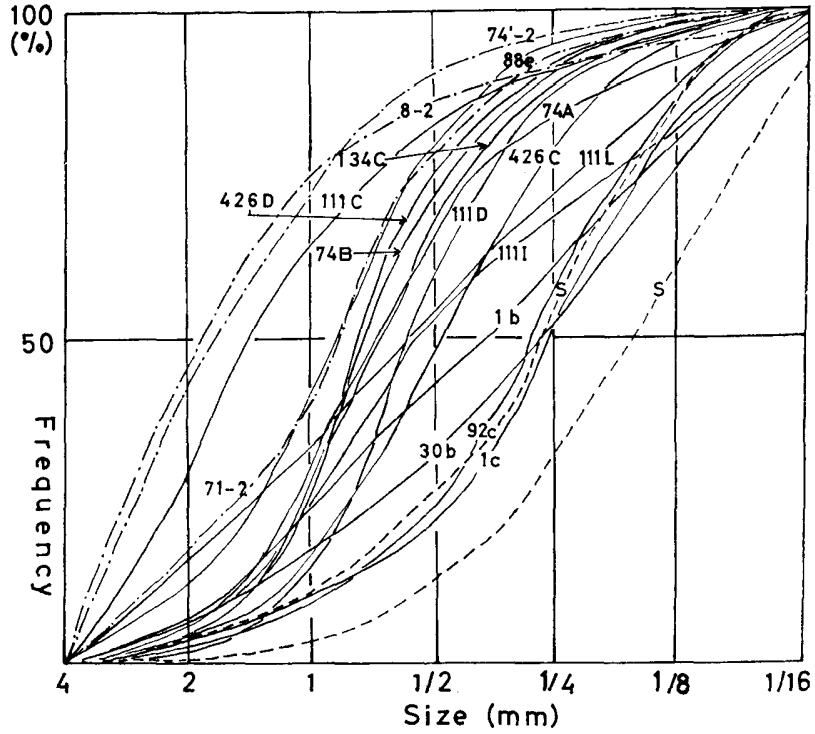

Fig. 4. Cumulative curves for the ash and pumice fall beds belonging to the Newer and Older Kirishima volcanics and for the Ôsumi pumice fall.

meter. The results are shown in Tables 5 and 6 and illustrated in Figs. 3, 4 and 5. 1) Size distribution for the "Shirasu" in the Takaharu area

The size distribution for the "Shirasu" in the Takaharu area shows incomplete or bad sorting. However, as is seen in Fig. 3, it is slightly well-sorted than the materials of the Ijûin-Miyanojô area, Kagoshima Prefecture (TANEDA et al., 1957). 


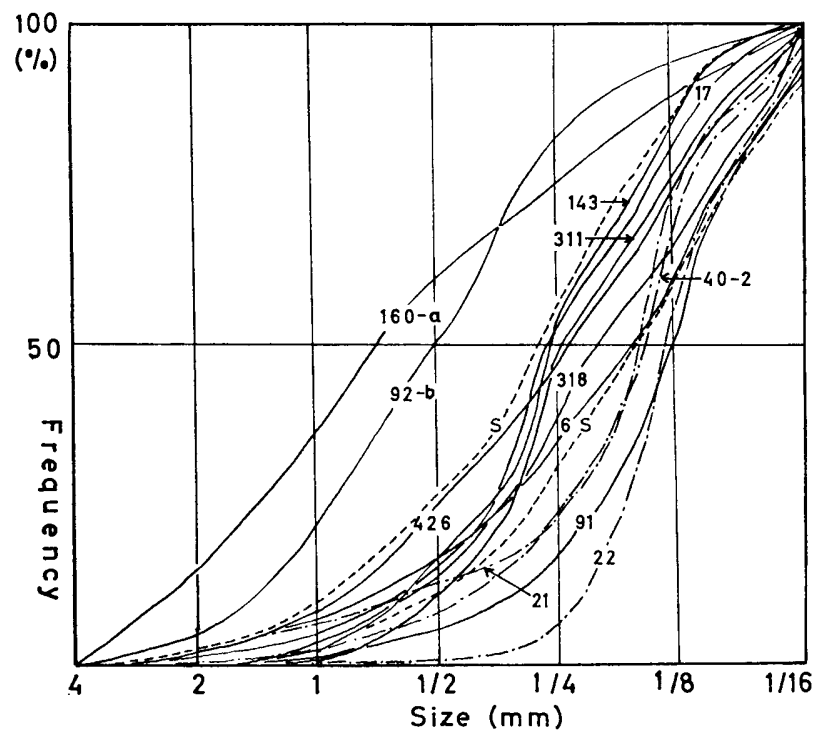

Fig. 5. Cumulative curves for the Shômyôji formation, Kokubu tuff, and "Secondary Shirasu."

2) Comparison of the pyroclastic fall deposit and the "Shirasu"

As is seen in Fig. 4, the pyroclastic fall deposits differ from the "Shirasu" in the size distribution. The analysed materials are (1) ash fall beds belonging to the Newer and Older Kirishima volcanic activities, (2) pumice fall beds belonging to the Older Kirishima activity, and the ôsumi pumice fall bed (ôTA, 1965) belonging to the Aira volcanic activity.

3) Comparison of the other pyroclastics and the "Shirasu"

The Shirasu-like deposit of "Shômyôji formation", the tuff of the Kokubu group, and the "Secondary Shirasu" were analysed mechanically. The "Shômyôji formation" cropping principally out the Kakutô Basin, Miyazaki Prefecture, is a lake deposit of the pumice flow (S. TANEDA, 1968). It is about 50 meter thick, unbedded, and resembles the "Shirasu" in appearance. The Kokubu tuff, usually well bedded, exposes mainly in the northern and north-western parts of the Kagoshima Bay.

As is clearly seen in Fig. 5, the three tuffs above mentioned are comparatively well-sorted than the "Shirasu".

The upper part of the "Shirasu" in this field shows partly a well-laminated or cross laminated structure (Nos.6,17, 143, 318, and 426), although they can not be distinguished from the massive and chaotic part of the "Shirasu" in the cumulative curves.

\section{Remarks}

1) In the Takaharu area, Miyazaki Prefecture, the northeast part of the "Shirasu Region", there are three pyroclastic flow deposits, the Hai-ishi I welded tuff, the Hai-ishi II welded tuff, and the Hai-ishi III welded tuff which grade to 
Table 5. Size distribution of the "Shirasu" in Takaharu area excluding large fragments exceeding $4 \mathrm{~mm}$ in diameter

\begin{tabular}{|c|c|c|c|c|c|c|c|c|}
\hline No. & $4-2$ & $2-1$ & $1-1 / 2$ & $1 / 2^{-1 / 4}$ & $1 / 4^{-1 / 8}$ & $1 / 8^{-1} / 16$ & $1 / 16>$ & $\mathrm{Md}$ \\
\hline 15 & 3 & 7 & 15 & 23 & 20 & 30 & 2 & 0.24 \\
\hline 74 & 2 & 6 & 17 & 24 & 26 & 24 & 1 & 0.25 \\
\hline 89 & 3 & 8 & 14 & 30 & 25 & 19 & 1 & 0.26 \\
\hline 92 & 2 & 6 & 13 & 24 & 27 & 24 & 4 & 0.22 \\
\hline 96 & 2 & 5 & 13 & 28 & 28 & 24 & 0 & 0.23 \\
\hline 97 & 1 & 6 & 15 & 28 & 27 & 21 & 2 & 0.25 \\
\hline 99 & 2 & 6 & 15 & 27 & 29 & 21 & 0 & 0.25 \\
\hline 101 & 2 & 4 & 12 & 34 & 26 & 22 & 0 & 0.25 \\
\hline 105 & 2 & 6 & 12 & 21 & 25 & 25 & 9 & 0.19 \\
\hline 108 & 1 & 3 & 14 & 33 & 34 & 15 & 0 & 0.26 \\
\hline 119 & 2 & 7 & 13 & 26 & 27 & 24 & 1 & 0.24 \\
\hline 125 & 3 & 8 & 14 & 21 & 28 & 25 & 1 & 0.23 \\
\hline 134 & 3 & 7 & 17 & 23 & 26 & 23 & 0 & 0.25 \\
\hline 140 & 2 & 6 & 13 & 28 & 32 & 18 & 1 & 0.25 \\
\hline 147 & 2 & 5 & 16 & 32 & 25 & 20 & 0 & 0.26 \\
\hline 161 & 2 & 8 & 13 & 32 & 28 & 17 & 0 & 0.27 \\
\hline 165 & 1 & 7 & 12 & 24 & 26 & 28 & 2 & 0.21 \\
\hline 170 & 3 & 5 & 16 & 27 & 26 & 23 & 0 & 0.25 \\
\hline 221 & 2 & 8 & 12 & 21 & 26 & 26 & 5 & 0.19 \\
\hline 225 & 2 & 5 & 10 & 21 & 23 & 32 & 7 & 0.17 \\
\hline 248 & 0 & 3 & 9 & 20 & 29 & 39 & 0 & 0.16 \\
\hline 259 & 0 & 6 & 17 & 30 & 27 & 20 & 0 & 0.26 \\
\hline 274 & 0 & 4 & 13 & 35 & 33 & 14 & 1 & 0.25 \\
\hline 278 & 2 & 8 & 12 & 28 & 32 & 18 & 0 & 0.25 \\
\hline 280 & 2 & 8 & 16 & 23 & 25 & 25 & 1 & 0.24 \\
\hline 309 & 2 & 7 & 16 & 21 & 21 & 31 & 2 & 0.21 \\
\hline 312 & 2 & 8 & 17 & 31 & 21 & 20 & 1 & 0.28 \\
\hline 313 & 2 & 8 & 15 & 20 & 24 & 29 & 2 & 0.21 \\
\hline 319 & 2 & 7 & 13 & 22 & 22 & 32 & 2 & 0.21 \\
\hline 346 & 2 & 5 & 13 & 22 & 24 & 32 & 2 & 0.19 \\
\hline 350 & 2 & 6 & 13 & 22 & 23 & 30 & 4 & 0.21 \\
\hline 360 & 3 & 6 & 13 & 26 & 26 & 25 & 1 & 0.23 \\
\hline 263 & 2 & 7 & 12 & 27 & 31 & 20 & 1 & 0.23 \\
\hline 367 & 2 & 6 & 15 & 25 & 29 & 23 & 0 & 0.24 \\
\hline 378 & 3 & 4 & 14 & 24 & 26 & 28 & 1 & 0.23 \\
\hline 432 & 1 & 7 & 14 & 23 & 28 & 26 & 1 & 0.22 \\
\hline 6 & 2 & 5 & 12 & 17 & 28 & 30 & 6 & 0.16 \\
\hline 17 & 0 & 4 & 11 & 39 & 27 & 19 & 0 & 0.26 \\
\hline 143 & 0 & 3 & 14 & 36 & 32 & 15 & 0 & 0.25 \\
\hline 318 & 1 & 5 & 11 & 23 & 27 & 33 & 1 & 0.20 \\
\hline 426 & 2 & 6 & 17 & 24 & 25 & 23 & 3 & 0.24 \\
\hline
\end{tabular}


Table 6. Size distribution of ash and pumice fall, sedimentary tuff, and "Secondary Shirasu"

\begin{tabular}{|c|c|c|c|c|c|c|c|c|c|}
\hline Name & No. & $4-2$ & $2-1$ & $1-1 / 2$ & $1 / 2^{-1 / 4}$ & $1 / 4^{-1 / 8}$ & $1 / 8^{-1 / 16}$ & $1 / 10>$ & $\mathrm{Md}$ \\
\hline \multirow{3}{*}{$\begin{array}{l}\text { Ôsumi } \\
\text { pumice fall }\end{array}$} & $8-2$ & 45 & 28 & 13 & 5 & 2 & 6 & 1 & 0.18 \\
\hline & $71-2$ & 17 & 20 & 41 & 14 & 6 & 2 & 0 & 0.84 \\
\hline & $74^{\prime}-2$ & 42 & 28 & 21 & 4 & 3 & 2 & 0 & 1.70 \\
\hline \multirow{2}{*}{$\begin{array}{l}\text { Older } \\
\text { Kirishima } \\
\text { pumice fall }\end{array}$} & $426-\mathrm{C}$ & 4 & 12 & 30 & 33 & 15 & 6 & 0 & 0.46 \\
\hline & $426-\mathrm{D}$ & 4 & 26 & 46 & 16 & 5 & 3 & 0 & 0.76 \\
\hline \multirow{7}{*}{$\begin{array}{l}\text { Older } \\
\text { Kirishima } \\
\text { ash fall }\end{array}$} & 74-A & 7 & 23 & 35 & 19 & 8 & 8 & 0 & 0.70 \\
\hline & $74-B$ & 4 & 23 & 45 & 19 & 7 & 2 & 0 & 0.74 \\
\hline & $111-C$ & 30 & 34 & 18 & 8 & 4 & 5 & 1 & 1.40 \\
\hline & $111-D$ & 2 & 13 & 44 & 28 & 8 & 4 & 1 & 0.56 \\
\hline & $111-\mathrm{I}$ & 6 & 19 & 25 & 18 & 13 & 19 & 0 & 0.52 \\
\hline & $111-\mathrm{L}$ & 15 & 18 & 20 & 19 & 14 & 14 & 0 & 0.54 \\
\hline & $134-\mathrm{C}$ & 3 & 20 & 42 & 24 & 8 & 3 & 0 & 0.65 \\
\hline \multirow{5}{*}{$\begin{array}{l}\text { Newer } \\
\text { Kirishima } \\
\text { ash fall }\end{array}$} & $1-b$ & 8 & 16 & 19 & 19 & 19 & 13 & 6 & 0.36 \\
\hline & $30-\mathrm{b}$ & 7 & 10 & 15 & 20 & 22 & 20 & 6 & 0.27 \\
\hline & $1-c$ & 4 & 6 & 12 & 32 & 27 & 17 & 2 & 0.26 \\
\hline & $92-\mathrm{c}$ & 3 & 7 & 14 & 34 & 27 & 14 & 1 & 0.27 \\
\hline & $88-\mathrm{e}$ & 13 & 23 & 41 & 16 & 3 & 2 & 0 & 0.80 \\
\hline \multirow{2}{*}{$\begin{array}{l}\text { Shômyôji } \\
\text { formation }\end{array}$} & 21 & 3 & 4 & 5 & 10 & 48 & 29 & 1 & 0.15 \\
\hline & 22 & 0 & 0 & 1 & 6 & 47 & 43 & 3 & 0.13 \\
\hline Kokubu tuff & $40-2$ & 0 & 1 & 7 & 16 & 47 & 26 & 4 & 0.14 \\
\hline \multirow{4}{*}{$\begin{array}{l}\text { "Secondary } \\
\text { Shirasu" }\end{array}$} & 91 & 0 & 2 & 5 & 11 & 37 & 37 & 8 & 0.13 \\
\hline & $92-b$ & 5 & 16 & 29 & 32 & 12 & 6 & 0 & 0.50 \\
\hline & $160-\mathrm{a}$ & 15 & 21 & 22 & 16 & 14 & 10 & 2 & 0.66 \\
\hline & 311 & 0 & 1 & 10 & 36 & 29 & 23 & 1 & 0.23 \\
\hline
\end{tabular}

three nonwelded pumice flows respectively. The Hai-ishi I welded tuff may be correlated with the TANEDA's older Kirishima pumice flow (1963) and the SAWAMURA's Haginomoto pumice flow (1956) on the basis of the lithologic feature and the optical constants of the constituent minerals. The Hai-ishi II welded tuff may be probably correlated stratigraphically and lithologically with the welded tuff forming the base of the Jyûsantsukahai Plateau, Kagoshima Prefecture. The Hai-ishi III welded tuff may grade to nonwelded pumice flow which is the writers' Shirasu (TANEDA, 1954, 1957; TANEDA et al., 1957) correlated with the "Ito pumice flow" and the "Ôsumi pumice flow".

2) The materials of pyroclastic flow deposit, fall deposit, and sedimentary tuff were analysed mechanically with sieves and were compared with each other. The characteristic of size distribution of the "Shirasu" in the Takaharu area belongs to that of pyroclastic flow deposit, which is distinguished in cumulative curve diagrams, from pyroclastic fall deposits. 


\section{Part V. The "Shirasu" in the Hitoyoshi Area, Kumamoto Prefecture}

(Mutsumi MiYACHI)

\section{Outline of geology and petrography}

The outline of geology in the Hitoyoshi area is shown in Table 7 and Fig. 6. The short descriptions on the main geologic units in this area are given below.

(1) The lowest one belonging to the Shimanto group exposes in the northern end of the area surveyed.

(2) The Hitoyoshi formation is a lake deposit of Plio-Pleistocene. Its total thickness attains to 500 or 600 meters. The lower part of the formation consists mainly of conglomerate, and the upper part mainly of greyish white mudstone accompanied with many thin layers of white tuff and sandstone.

Table 7. General stratigraphic succession

\begin{tabular}{|c|c|c|}
\hline Age & Hitoyoshi area & \\
\hline Alluvium & $\begin{array}{l}\begin{array}{l}\text { Alluvial deposits } \\
\text { Loam }\end{array} \\
\text { Newer gravel bed }\end{array}$ & \\
\hline \multirow{4}{*}{ Pleistocene } & "Shirasu" & Aira volcanism \\
\hline & $\begin{array}{l}\text { Black Aso welded tuff } \\
\text { gravel }\end{array}$ & Aso volcanism \\
\hline & $\begin{array}{l}\text { Grey welded tuff II } \\
\text { gravel }\end{array}$ & Kakuto volcanism ? \\
\hline & Grey welded tuff I & Kakuto volcanism? \\
\hline \multirow{2}{*}{$\begin{array}{l}\text { Plio- Plei- } \\
\text { stocene }\end{array}$} & Andesite complex & \\
\hline & Hitoyoshi formation & \\
\hline Mesozoic & Shimanto group & \\
\hline
\end{tabular}

(3) The andesite group, which is mainly distributed in the southern part of this area, is composed of the lava flows of olivine-bearing two pyroxene andesite, hornblende-bearing two pyroxene andesite, and two pyroxene andesite. Their stratigraphical relations are not always clear.

(4) The grey welded tuff I is distributed only in the southern side of the Kuma river. At the banks of the Hatomune river in Okoba, Hitoyoshi City, the welded tuff unconformably overlies the olivine-bearing two pyroxene andesite lava above mentioned. It is grey to greyish white colored, about 20 meter thick, and characterized by hornblende phenocrysts. At Tamachi, Hitoyoshi City, it is covered by a gravel bed, 3 meters thick, which is covered moreover by the grey welded tuff II described in the next section. At Gansaku, on the other hand, it is covered by the black Aso welded tuff directly. 


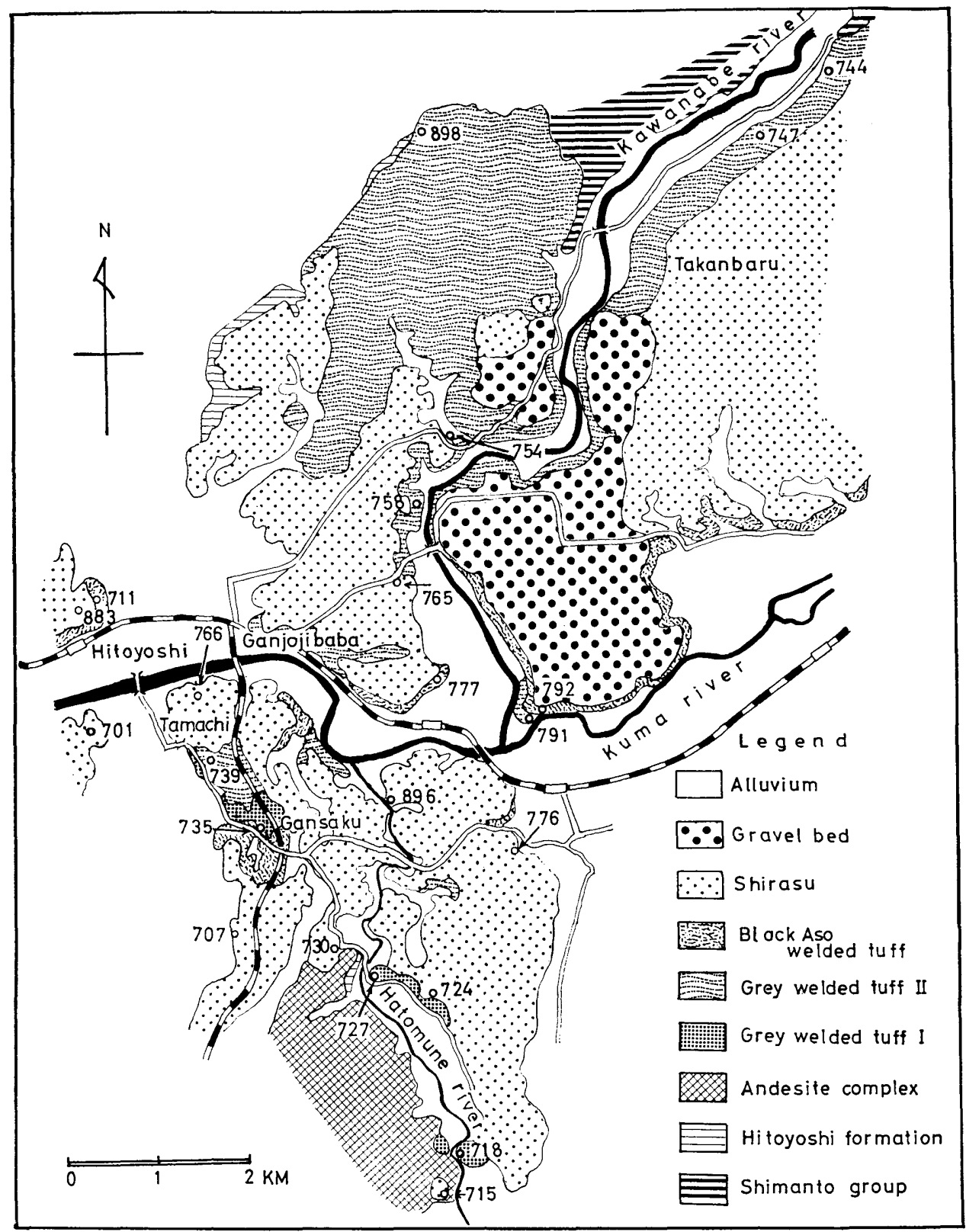

Fig. 6. Geologic map of the Hitoyoshi area.

In thin section, it shows a welding texture with the phenocrystic plagioclase, green hornblende, quartz, a less amount of hypersthene, and augite in the groundmass composed of colorless or pale brownish yellow glass, containing a less amount of flakes of plagioclase, pyroxene, hornblende, and iron ores. The optical constants of the constituent minerals are shown in Table 8.

The grey welded tuff I can be correlated with the Middle welded tuff (TANEDA, et al., 1957) in the northwest part of Kagoshima Prefecture, or with the welded 
Table 8. Optical constant for the constituent minerals of three welded tuffs and the "Shirasu"

\begin{tabular}{|c|c|c|c|c|c|c|c|c|}
\hline \multirow{2}{*}{ Rock name } & \multirow{2}{*}{ No. } & \multicolumn{2}{|c|}{ Plagioclase } & \multicolumn{2}{|c|}{ Hypersthene } & \multicolumn{2}{|c|}{ Hornblende } & \multirow{2}{*}{$\frac{\text { Glass }}{n}$} \\
\hline & & $\mathrm{n}_{1 \min }$ & $\mathrm{n}_{2 \max }$ & $\alpha_{\min }$ & $\gamma_{\max }$ & $\mathrm{n}_{1 \text { min }}$ & $\mathrm{n}_{2 \max }$ & \\
\hline \multirow{4}{*}{$\begin{array}{l}\text { Grey welded } \\
\text { tuff I }\end{array}$} & 718 & 1.549 & 1.556 & 1.693 & 1.706 & 1.648 & 1.670 & 1.498 \\
\hline & 728 & 1.549 & 1.556 & 1.694 & 1.706 & 1.650 & 1.668 & 1.498 \\
\hline & 735 & 1.548 & 1.557 & 1.693 & 1.708 & 1.654 & 1.674 & \\
\hline & 565 & 1.545 & 1.557 & 1.694 & 1.707 & 1.652 & 1.674 & \\
\hline \multirow{2}{*}{$\begin{array}{l}\text { Middle welded } \\
\text { tuff }\end{array}$} & 7281 & 1.547 & 1.558 & 1.692 & 1.708 & 1.654 & 1.669 & \\
\hline & 33 & 1.548 & 1.558 & 1.692 & 1.708 & 1.650 & 1.667 & 1. $495-1.498$ \\
\hline \multirow{2}{*}{$\begin{array}{l}\text { Kawachi pyro- } \\
\text { clastic flow }\end{array}$} & 62 & 1.547 & 1.558 & 1.695 & 1.705 & 1.648 & 1.669 & \\
\hline & 66 & 1.548 & 1.559 & 1.693 & 1.708 & 1.648 & 1.670 & \\
\hline \multirow{6}{*}{$\begin{array}{l}\text { Grey welded } \\
\text { tuff II }\end{array}$} & 739 & 1.549 & 1.562 & 1.700 & 1.720 & \multirow{2}{*}{\multicolumn{2}{|c|}{ none }} & $1.499-1.501$ \\
\hline & 744 & 1.548 & 1.559 & 1.704 & 1.722 & & & \\
\hline & 747 & 1.549 & 1.562 & 1.702 & 1.722 & \multicolumn{2}{|c|}{$\begin{array}{l}\text { none } \\
\text { none }\end{array}$} & $1.498-1.499$ \\
\hline & 758 & 1.550 & 1.564 & 1.702 & 1.721 & \multicolumn{2}{|c|}{ none } & $1.496-1.500$ \\
\hline & 898 & 1.549 & 1.560 & 1.700 & 1.724 & \multicolumn{2}{|c|}{ none } & \\
\hline & 791 & 1.550 & 1.563 & n.d. & n.d. & \multicolumn{2}{|c|}{ none } & $1.497-1.503$ \\
\hline \multirow{3}{*}{$\begin{array}{l}\text { Black Aso } \\
\text { welded tuff }\end{array}$} & 711 & 1.548 & 1.560 & \multirow{3}{*}{\multicolumn{2}{|c|}{$\begin{array}{l}\text { none } \\
\text { none } \\
\text { rare }\end{array}$}} & 1.668 & 1.688 & 1.509 \\
\hline & 777 & 1.548 & 1.559 & & & 1.668 & 1.688 & 1.510 \\
\hline & 792 & 1.546 & 1.560 & & & 1.668 & 1.688 & 1.511 \\
\hline \multirow{5}{*}{ "Shirasu" } & 701 & 1.548 & 1.558 & 1.706 & 1.726 & \multicolumn{2}{|c|}{ none } & 1.501 \\
\hline & 724 & 1.548 & 1.560 & 1.706 & 1.726 & \multicolumn{2}{|c|}{ none } & $1.496-1.502$ \\
\hline & 730 & 1.546 & 1.556 & 1.707 & 1.726 & \multicolumn{2}{|c|}{ none } & $1.496-1.502$ \\
\hline & 883 & 1.548 & 1.558 & 1.706 & 1.726 & \multicolumn{2}{|c|}{ none } & $1.496-1.503$ \\
\hline & 896 & 1.547 & 1.556 & 1.706 & 1.725 & \multicolumn{2}{|c|}{ none } & $1.496-1.503$ \\
\hline
\end{tabular}

7281: Uranomyô, Iriki Town, Kagoshima Prefecture, 33: Tônoharu, Hiwaki Town, Kagoshima Prefecture.

tuffs of the other areas in Kagoshima and Miyazaki Prefectures.

1. Iino, Ebino Town, Miyazaki Prefecture (Sample No.565).

2. Kawachi, Kokubu City, Kagoshima Prefecture (Sample No. 62).

3. Ushine-fumoto, Tarumizu City, Kagoshima Prefecture (Sample No. 66). The optical constants of the constituent minerals of these welded tuffs are shown in Table 2 also.

(5) The grey welded tuff II forms a large plateau named the Takanbaru, northeast of Hitoyoshi City. It attains 50 meters in the left bank of Kawabe river in the maximum thickness. The rock facies is very variable. At an outcrop in Ganjôji-baba, near the Higashi-Hitoyoshi Station, two different facies are observed. The upper part is non-welded and contains a number of pumice and lithic fragments, while the lower part is perfectly welded and contains no essential and accidental inclusions. The boundary between the lower glassy part and the upper part is gradational from one to another. But, at the other exposures the 
boundary is sharply discontinuous (TAMURA, et al., 1962). The lower glassy part shows a typical welding texture in thin section. The phenocrysts are plagioclase and hypersthene. Plagioclase is 1 to $1.5 \mathrm{~mm}$ in diameter, mostly fragmentary and rarely euhedral. Hypersthene is very rare. Microphenocrysts of augite are rarely present. The groundmass consists of pale yellow or colorless glass with accessory magnetite, ilmenite, and zircon. The optical constants for the constituent minerals of the grey welded tuff II are shown in Table 8.

At Kamikawabe (No.744), the north-eastern end of the Takanbaru Plateau, the lowermost part of the grey welded tuff II resembles closely in appearance the Hai-ishi I welded tuff exposed in the Takaharu area, Miyazaki Prefecture. The optical constants for the constituent minerals of the welded tuff coincide with those of the Hai-ishi I welded tuff. The grey welded tuff II, therefore, can be partly correlated with the Hai-ishi I welded tuff (the Haginomoto pumice flow). It is not, however, known yet whether the whole welded tuff is identified perfectly with the Hai-ishi I welded tuff or not. More detailed volcano-stratigraphical and petrographical investigations are necessary to clear up the relations.

(6) The black Aso welded tuff, 10 meters in thickness, is distributed mainly in the northern side of the Kuma river. In the southern side, at Gansaku and at the north and west flanks of Mt. Amabukiyama, there are many small outcrops. The upper- and lowermost 1 to 0.5 meters of a complete section are loose ash, and the middle part is slightly welded. Pumice fragments and lithic inclusions are very rare. In many places of this field the black Aso welded tuff is unconformably covered by the "Shirasu" belonging to the Aira volcanics.

In thin section, it consists mainly of light brown to brown glass flakes, and a less amount of phenocrystic minerals, plagioclase and green hornblende. Optic constants for the constituent minerals are shown in Table 8.

(7) The "Shirasu" is light grey to white non-welded pumice flow deposit, approximately 10 meters in thickness. A less amount of pumice and lithic fragments are generally $10 \mathrm{~mm}$ or below in diameter. The uppermost 5 meters is well sorted into coarse and fine layers and locally shows cross-bedding. The uppermost part can be correlated with the so-called "Secondary Shirasu" in the Takaharu area, Miyazaki Prefecture.

The constituent minerals of the matrix of the "Shirasu" are colorless glass and a less amount of crystals of plagioclase, hypersthene, quartz and augite. Hornblende is not found.

\section{Size distribution}

The eight samples of the "Shirasu" from different localities in this area and of the upper non-welded part of the black Aso welded tuff from three localities were analysed mechanically with sieves, excluding large fragments exceeding $4 \mathrm{~mm}$ in diameter. The results are shown in Table 9.

(1) The size distribution for the "Shirasu" in this area, which occupies the northern end of the "Shirasu Region" shows also characteristic of a pyroclastic flow deposit. 


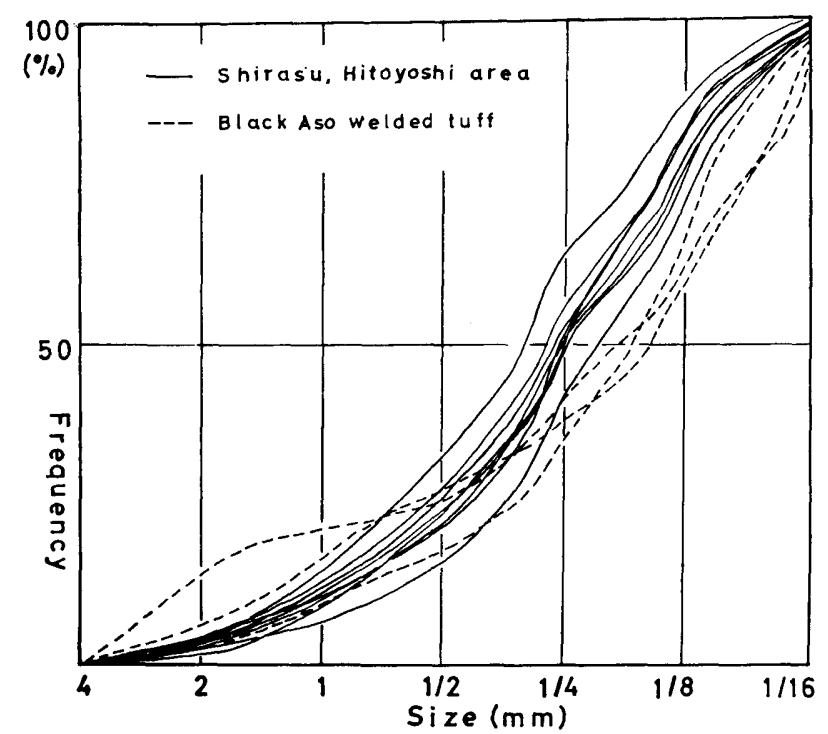

Fig. 7. Cumulative curves of size distribution for the "Shirasu" and nonwelded part of the black Aso welded tuff.
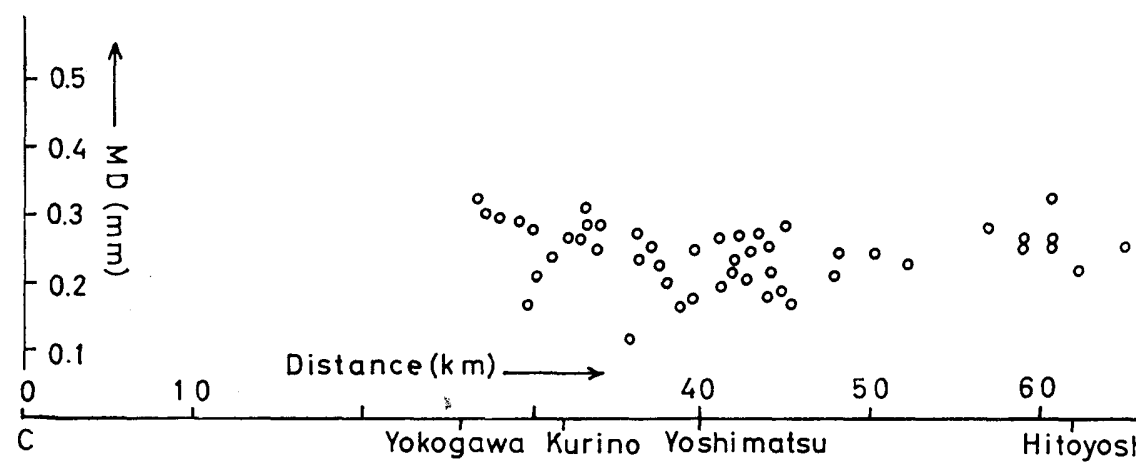

Fig. 8. Variation of Md value for the "Shirasu" along the line between Yokogawa and Hitoyoshi.

Figures: Distance $(\mathrm{Km})$ measured from the center of the Aira caldera.

(2) The size distribution for the black Aso welded tuff is also of a pyroclastic flow type.

(3) The relation between the median diameter (Md) and the distance from the center of the Aira caldera is not clear (Fig. 8). Concerning with the pyroclastic fall deposit, on the contrary, the variation of the median diameter with the increase of the distance from the center of the Aira caldera is very distinct.

\section{Correlation and Remarks}

In the Hitoyoshi area, Kumamoto Prefecture (the northern end of the "Shirasu Region") four different pyroclastic flow deposits are occurred. They are, from the lower, the grey welded tuff I, the grey welded tuff II, black Aso 
Part V. The "Shirasu" in the Hitoyoshi Area, Kumamoto Prefecture

Table 9. Size distribution of the "Shirasu" in the Hitoyoshi area and upper non-welded part of the black Aso welded tuff

\begin{tabular}{|c|c|c|c|c|c|c|c|c|c|}
\hline \multicolumn{2}{|c|}{$\frac{\text { size }(\mathrm{mm})}{\mathrm{No} .}$} & $4-2$ & $2-1$ & $1-1 / 2$ & $1 / 2^{-1 / 4}$ & $1 / 4^{-1 / 8}$ & $1 / 8^{-1 / 16}$ & $1 / 16>$ & $\mathrm{Md}$ \\
\hline \multirow{8}{*}{ "Shirasu" } & 701 & 4 & 12 & 17 & 27 & 24 & 16 & 0 & 0.32 \\
\hline & 707 & 4 & 9 & 12 & 26 & 25 & 23 & 1 & 0.26 \\
\hline & 715 & 3 & 9 & 15 & 30 & 26 & 16 & 1 & 0.28 \\
\hline & 730 & 3 & 7 & 11 & 29 & 27 & 21 & 2 & 0.25 \\
\hline & 754 & 4 & 8 & 9 & 31 & 31 & 16 & 1 & 0.25 \\
\hline & 765 & 2 & 6 & 9 & 27 & 26 & 28 & 2 & 0.21 \\
\hline & 766 & 3 & 8 & 14 & 28 & 32 & 13 & 2 & 0.25 \\
\hline & 776 & 2 & 8 & 13 & 27 & 28 & 20 & 2 & 0.25 \\
\hline \multirow{3}{*}{ Aso IV } & 703 & 3 & 7 & 8 & 17 & 24 & 39 & 2 & 0.17 \\
\hline & 711 & 15 & 6 & 6 & 8 & 25 & 38 & 2 & 0.15 \\
\hline & $A_{1} *$ & 7 & 11 & 9 & 15 & 21 & 35 & 2 & 0.17 \\
\hline
\end{tabular}

* Sample from Nakagawa Town, Fukuoka Prefecture

welded tuff, and the "Shirasu".

The grey welded tuff I can be correlated with the Middle welded tuff of Miyanojô-Hiwaki area studied by TANEDA et al., and with the welded tuffs exposed in small exposures at Kawachi, Kokubu City, Kagoshima Prefecture, at Ushine-fumoto, Tarumizu City, Kagoshima Prefecture, and at Iino, Ebino Town, Miyazaki Prefecture. It is considered that the grey welded tuff I was not erupted from the Aira caldera volcano, but from a more northern place such as the Kakuto caldera volcano proposed by ARITA (1957).

The grey welded tuff II may be correlated partly with the Hai-ishi I welded tuff in the Takaharu area, Miyazaki Prefecture, by the similar lithology and optic constants of the constituent minerals. About the eruptive source it is considered to belongs to the Kakuto caldera volcanism.

The black Aso welded tuff can be correlated with the Aso IV sheet by ONo (1965), which is a welded tuff erupted in the latest stage from the Aso caldera volcano (MATSUMoto, 1943).

The "Shirasu" in this area can be identified lithologically and petrographically with the "Shirasu proper" spread over the wide area of Kagoshima Prefecture. It was erupted from the Aira caldera volcano.

The size distribution for the "Shirasu" in this area, is also a pyroclastic flow type. The relation between median diameter and the distance from the center of the Aira caldera is not clear.

Acknowledgements I wish to express my sincere thanks to Professor S. TANEdA for his kind guidance and criticism for this study. 


\section{Part VI. The "Shirasu" in the southwestern part of the Satsuma Peninsula, Kagoshima Prefecture}

(Sadakatu TANedA, Jun-nosuke MoRIta, Mutumi MiYaCHI)

\section{Outline of geology and petrography}

The outline of geology in the southwestern part of the Satsuma Peninsula is shown in Table 10 and Fig. 9. The brief descriptions on the main geologic units in this area are given below.

Table 10. Stratigraphic succession of the southwestern Satsuma Peninsula

\begin{tabular}{|c|c|c|}
\hline Age & Stratigraphy & Description \\
\hline Recent & $\begin{array}{l}\text { Loam } \\
\text { Talus deposite }\end{array}$ & $\begin{array}{l}\text { Ash fall, sand and gravel beds, } \\
\text { river talus }\end{array}$ \\
\hline \multirow{2}{*}{ Pleistocene } & "Shirasu" & Aira volcanism \\
\hline & Ata pyroclastic flow deposit & Ata volcanism \\
\hline Pliocene & Nansatsu andesites & $\begin{array}{l}\text { Two pyroxene andesites, hornblende } \\
\text { andesites, with their tuff breccia, } \\
\text { and conglomerates, sandstones, tufa- } \\
\text { ceous shales }\end{array}$ \\
\hline Miocene & Kaseda acid rocks & $\begin{array}{l}\text { Granite, granite porphyry, rhyolite } \\
\text { porphyry, rhyolite, augite porphy- } \\
\text { rite, and others } \\
\quad \text { Stock, dyke, sill }\end{array}$ \\
\hline Up. Jura. & $\begin{array}{l}\text { Unknown Mesozoic forma- } \\
\text { tions }\end{array}$ & $\begin{array}{l}\text { Sandstone, shale, alternation of } \\
\text { sandstone and shale, limestone and } \\
\text { conglomerate }\end{array}$ \\
\hline
\end{tabular}

(1) The basement is the so-called "Unknown Mesozoic formation" exposed shale and their alternations accompanied with conglomerate and limestone. In shale and their alternations accompanied with conglomerate and limestone. From the limestone in the vicinity of the Noma-ike some fossils of the "Torinosu type" have been found (EGUCHI, 1942).

(2) The "Kaseda acid rocks" are intruded discordantly into the Mesozoic formation above mentioned in Miocene. These rocks consist of biotite granite, granite-porphyry, rhyolite-porphyry, porphyritic rhyolite, augite gabbro-porphyrite, hornblende diorite-porphyry, and granitic aplite. In the Kaseda district the acid rocks grades gradually in rock facies from plutonic to effusive (graniteporphyritic rocks-rhyolite) without accompanying any basic rock. On the other hand in the Noma district, the basic plutonic rocks grade to acid effusive rocks (gabbro-porphyrite-diorite-porphyrite-rhyolite-prophyry).

The Kaseda acid rocks occur in various forms as stock, dyke and sill, all of which may be apophyses of a large body in the depth.

(3) The "Nansatsu andesites" are lava flows consisting of two pyroxene andesite and hornblende andesite, tuffs and tuff breccias together with underlying 


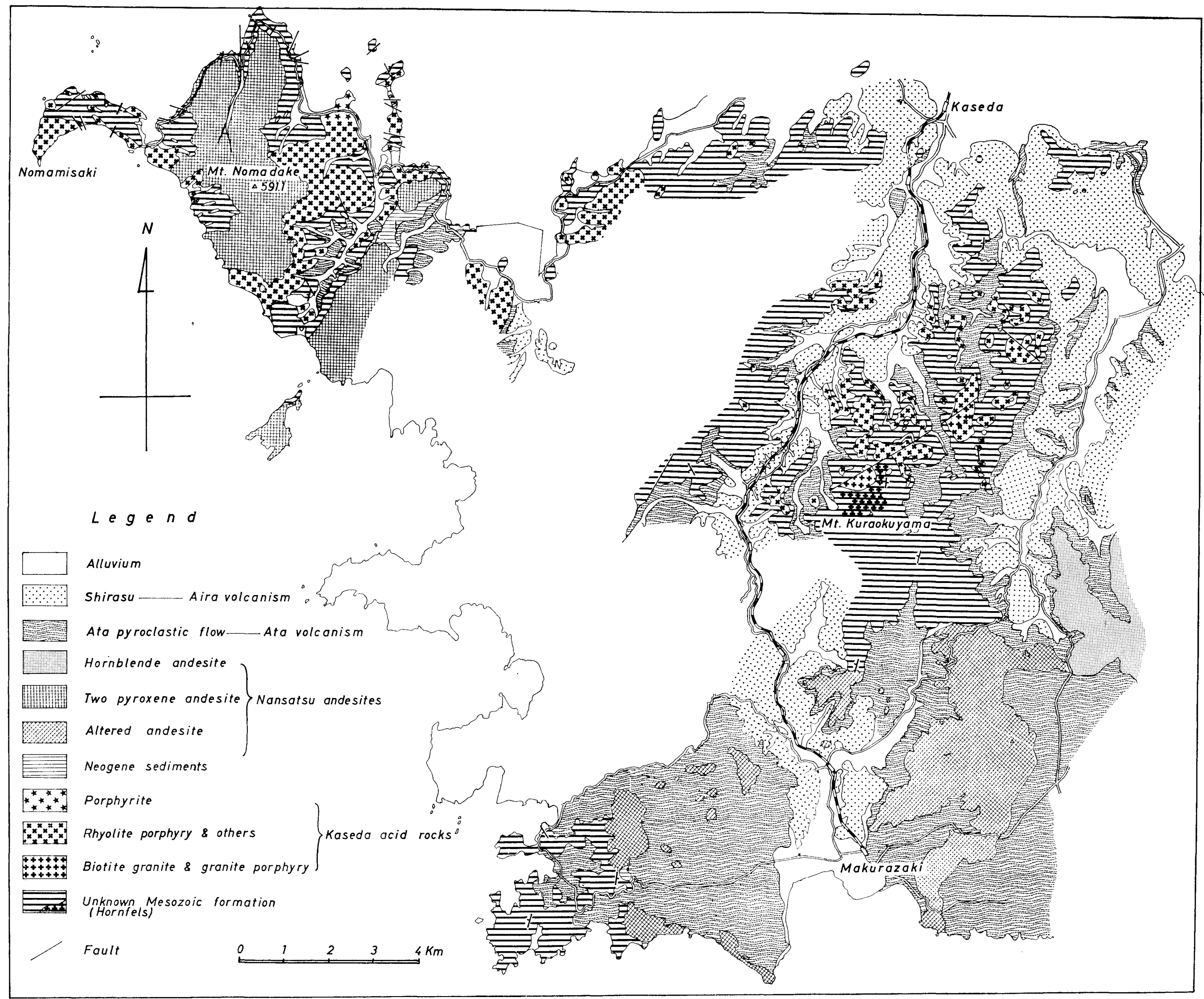

Fig. 9. Geologic map of the southwestern Satsuma Peninsula. 


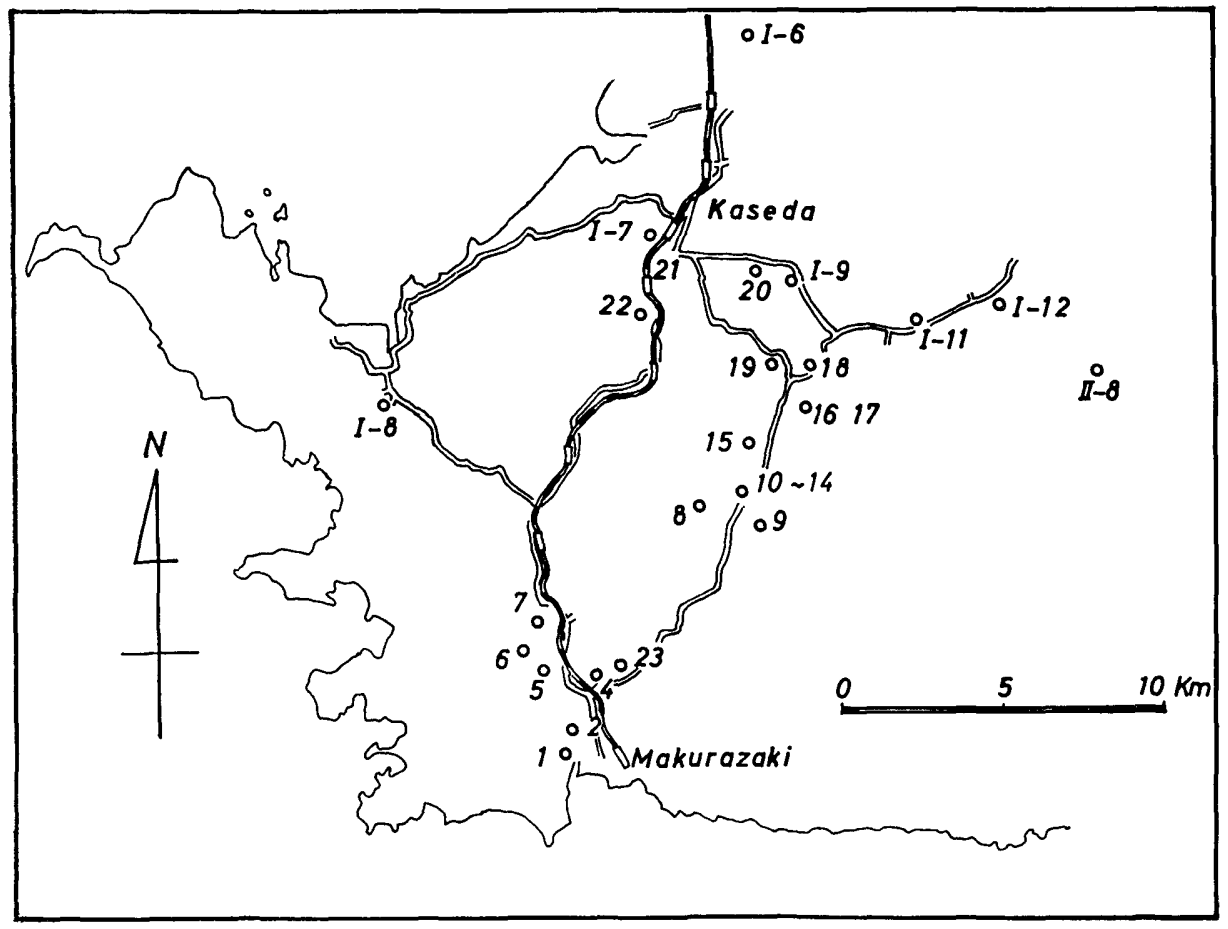

Fig. 10. Sample locality map of the "Shirasu."

Table 11. Refractive indices of plagioclase, hypersthene, and volcanic glass for the Ata pyroclastics and the "Shirasu"

\begin{tabular}{|c|c|c|c|c|c|c|c|}
\hline \multirow{2}{*}{ Name } & \multirow{2}{*}{\multicolumn{2}{|c|}{$\frac{\text { Mineral }}{\text { No. }}$}} & \multicolumn{2}{|c|}{ Plagioclase } & \multicolumn{2}{|c|}{ Hypersthene } & \multirow{2}{*}{ Glass } \\
\hline & & & $\mathrm{n}_{1 \text { min }}$ & $\mathrm{n}_{2 \max }$ & $\alpha_{\min }$ & $\gamma_{\max }$ & \\
\hline \multirow{4}{*}{$\begin{array}{l}\text { Ata } \\
\text { pyroclastic } \\
\text { flow }\end{array}$} & upper & 8024 & 1.553 & 1.564 & 1.691 & 1.709 & n.d. \\
\hline & middle & 4060 & 1.554 & 1.563 & 1.691 & 1.707 & n.d. \\
\hline & lower & 7191 & 1.555 & 1.563 & 1.690 & 1.706 & $1.512 \sim 1.513$ \\
\hline & lower & 7192 & 1.556 & 1.564 & 1.689 & 1.706 & $1.510 \sim 1.511$ \\
\hline \multirow{3}{*}{\multicolumn{2}{|c|}{ "Shirasu" }} & I-7 & 1.550 & 1.556 & 1.710 & 1.726 & 1.499 \\
\hline & & $\mathrm{I}-12$ & 1.549 & 1.556 & 1.707 & 1.725 & 1.498 \\
\hline & & II-8 & 1.550 & 1.556 & 1.709 & 1.727 & 1.499 \\
\hline
\end{tabular}

thin sediments. The two pyroxene andesite is alterated partly into propylitic andesite and silicified andesite. In Fig. 9 these andesites are shown as the altered andesites. In the silicified part, are present some pneumatolytic gold deposits such as the Kasuga Mine deposit.

(4) The "Ata pyroclastic flow deposit", which is covered unconformably by the "Shirasu", is a typical welded tuff. It is divided by the lithological feature into three different facies, which are gradational from one to the other in this field. The lower part is black to dark grey glassy welded tuff. The middle part is a greyish pink welded tuff. The upper one is reddish brown to black welded 
tuff, showing a fluidal structure as is seen in andesite lava flow.

Under the microscope it shows a porphyritic texture with the phenocrysts of plagioclase, hypersthene and augite. Plagioclase is 0.5 to $1 \mathrm{~mm}$ in length, subhedral or flaky, and rarely shows a zonal structure. Hypersthene is short prismatic, $1 \mathrm{~mm}$ in length and shows strong pleochroism. Augite is short prismatic form

Table 12. Chemical composition of the "Shirasu" in Yaji, Kaseda City, Kagoshima Prefecture.

Analyst: Junnosuke MoRITA

\begin{tabular}{l|r|rr}
\hline & Wt. \% & \multicolumn{2}{|c}{ Norm } \\
\hline $\mathrm{SiO}_{2}$ & 68.86 & $\mathrm{Q}$ & 31.86 \\
$\mathrm{Al}_{2} \mathrm{O}_{3}$ & 15.00 & or & 14.46 \\
$\mathrm{Fe}_{2} \mathrm{O}_{3}$ & 0.95 & $\mathrm{ab}$ & 29.34 \\
$\mathrm{FeO}$ & 1.91 & an & 13.34 \\
$\mathrm{MgO}$ & 0.64 & $\mathrm{C}$ & 1.43 \\
$\mathrm{CaO}$ & 2.83 & en & 1.60 \\
$\mathrm{Na}_{2} \mathrm{O}$ & 3.45 & fs & 1.72 \\
$\mathrm{~K}_{2} \mathrm{O}$ & 2.43 & $\mathrm{mt}$ & 1.39 \\
$\mathrm{TiO}_{2}$ & 0.57 & il & 1.06 \\
$\mathrm{P}_{2} \mathrm{O}_{5}$ & 0.15 & ap & 0.34 \\
$\mathrm{MnO}$ & 0.16 & & \\
$\mathrm{H}_{2} \mathrm{O}_{+}$ & 2.39 & & \\
$\mathrm{H}_{2} \mathrm{O}-$ & 0.66 & & \\
\hline Total & 100.00 & & \\
\hline
\end{tabular}

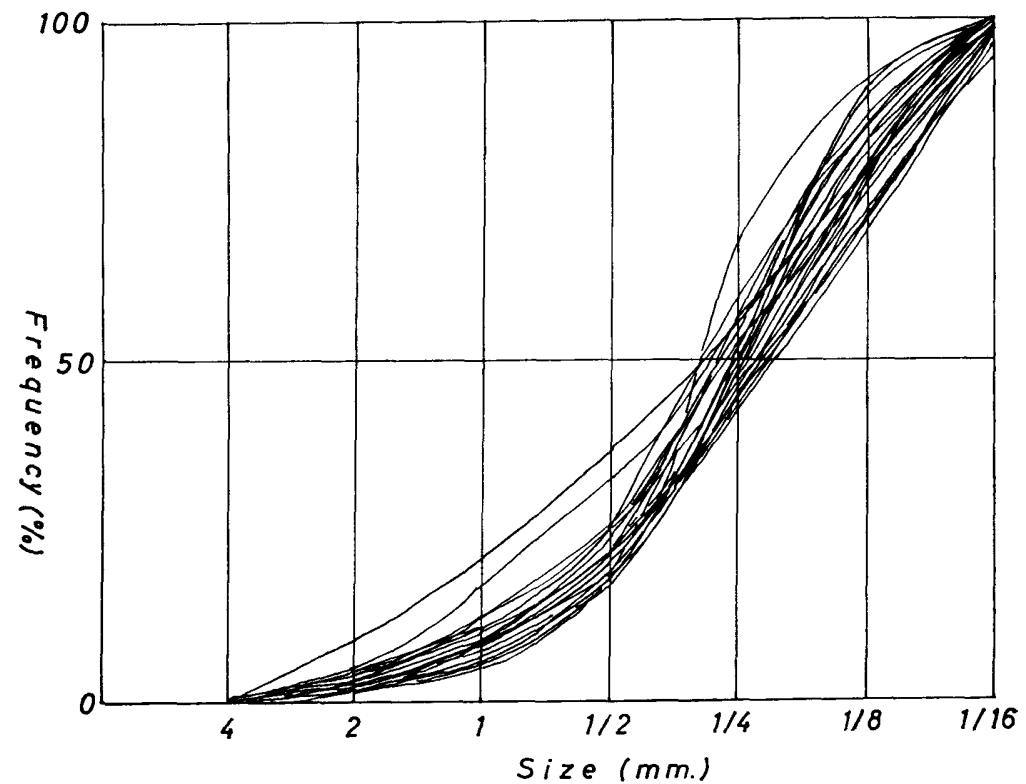

"Fig. 11. Cumulative curves for the Shirasu." 
Part VI. The "Shirasu" in the South Satsuma, Kagoshima Prefecture

Table 13. Size distribution of the "Shirasu," excluding large fragments exceeding $4 \mathrm{~mm}$ in diameter

\begin{tabular}{|c|c|c|c|c|c|c|c|c|}
\hline $\begin{array}{|cc|} & \text { Size } \\
\text { No. } & (\mathrm{mm}) \\
\end{array}$ & $4-2$ & $2-1$ & $1-1 / 2$ & $1 / 2^{-1 / 4}$ & $1 / 4^{-1 / 8}$ & $1 / 8^{-1} / 16$ & $1 / 16>$ & $\mathrm{Md}$ \\
\hline 1 & 8 & 13 & 15 & 19 & 21 & 23 & 1 & 0.30 \\
\hline 2 & 2 & 4 & 12 & 33 & 40 & 9 & 0 & 0.26 \\
\hline 4 & 3 & 6 & 12 & 23 & 26 & 28 & 2 & 0.22 \\
\hline 5 & 2 & 6 & 12 & 24 & 26 & 25 & 5 & 0.22 \\
\hline 6 & 1 & 3 & 11 & 26 & 27 & 23 & 7 & 0.20 \\
\hline 7 & 3 & 5 & 13 & 34 & 34 & 11 & 0 & 0.28 \\
\hline 8 & 1 & 6 & 12 & 30 & 32 & 18 & 1 & 0.24 \\
\hline 9 & 2 & 6 & 11 & 28 & 35 & 18 & 0 & 0.24 \\
\hline 10 & 2 & 4 & 12 & 32 & 33 & 16 & 1 & 0.25 \\
\hline 1 & 2 & 6 & 9 & 28 & 33 & 21 & 1 & 0.22 \\
\hline 2 & 1 & 4 & 12 & 31 & 33 & 18 & 1 & 0.24 \\
\hline 3 & 2 & 5 & 13 & 25 & 32 & 22 & 1 & 0.22 \\
\hline 4 & 1 & 3 & 13 & 41 & 27 & 14 & 1 & 0.28 \\
\hline 5 & 2 & 6 & 15 & 24 & 33 & 18 & 2 & 0.24 \\
\hline 6 & 3 & 6 & 13 & 24 & 26 & 23 & 5 & 0.23 \\
\hline 7 & 1 & 5 & 13 & 25 & 32 & 23 & 1 & 0.22 \\
\hline 8 & 3 & 8 & 13 & 36 & 24 & 15 & 1 & 0.30 \\
\hline 9 & 2 & 5 & 14 & 22 & 25 & 29 & 3 & 0.21 \\
\hline 20 & 3 & 7 & 12 & 29 & 31 & 17 & 1 & 0.25 \\
\hline 1 & 2 & 8 & 11 & 29 & 35 & 14 & 1 & 0.25 \\
\hline 2 & 2 & 6 & 15 & 28 & 26 & 22 & 1 & 0.26 \\
\hline 3 & 2 & 6 & 12 & 23 & 27 & 24 & 6 & 0.21 \\
\hline I- 6 & 3 & 9 & 12 & 23 & 28 & 23 & 2 & 0.24 \\
\hline I- 8 & 1 & 6 & 11 & 48 & 26 & 8 & 1 & 0.28 \\
\hline I- 9 & 1 & 7 & 10 & 32 & 27 & 21 & 2 & 0.25 \\
\hline I-11 & 2 & 10 & 13 & 27 & 23 & 21 & 4 & 0.26 \\
\hline I-12 & 3 & 14 & 15 & 24 & 22 & 19 & 3 & 0.28 \\
\hline
\end{tabular}

with 0.5 to $1 \mathrm{~mm}$ length. Refractive indices for hypersthene, plagioclase and volcanic glass are shown in Table 11.

(5) The "Shirasu" is a pumice flow deposit of 40 meters thick which is a light grey to white, non-consolidated bed. It is composed mainly of pumice fragments, glass flakes, lithic fragments, and a small amount of crystal grains, which are plagioclase, quartz, hypersthene, and augite. Refractive indices for these crystals and volcanic glass are also shown in Table 11.

Chemical composition of the "Shirasu" from Yaji, Kaseda City, is as follows (Table 12).

\section{Size distribution}

The samples of the Shirasu from twenty-seven localities in this area was analysed mechanically with sieves. The results are shown in Table 13 and illus- 


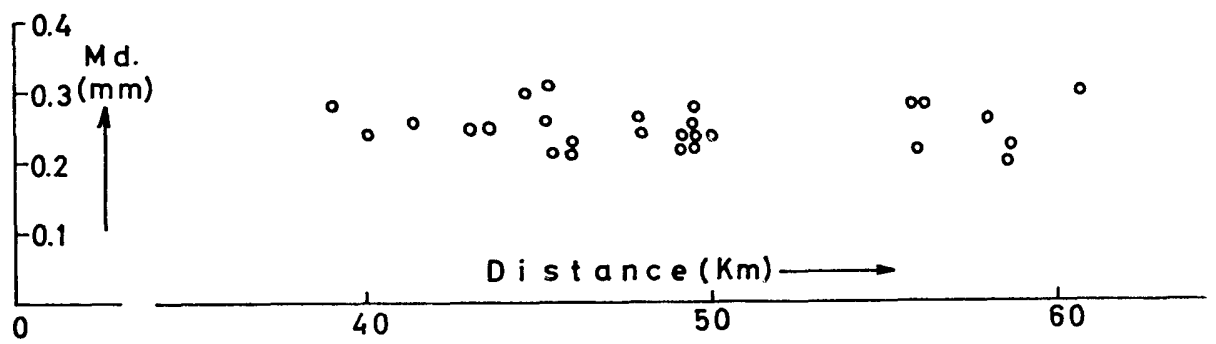

Fig. 12. Variation of $\mathrm{Md}$ from the center of the Aira caldera to Makurazaki City.

trated in Fig. 11. The size distribution for the "Shirasu" in this area where is the southwestern end of the "Shirasu Region", shows also the characteristic of pumice flow deposit.

The relation between median diameter and the distance from the center of the Aira caldera is no distinctive as shown in Fig. 12.

\section{Remarks}

In the southwestern Satsuma Peninsula, Kagoshima Prefecture, where is the southwestern end of the "Shirasu Region", two pyroclastic flow deposits erupted from the different eruptive source are exposed. One of them is the Ata pyroclastic flow deposit erupted from the Ata caldera volcano. Another is the "Shirasu" erupted from the Aira caldera volcano.

The size distribution for the "Shirasu" in this area shows an incomplete or bad sorting which is one of the characteristic of a pumice flow deposit. The relation between median diameter and the distance from the center of the Aira caldera is not clear. 


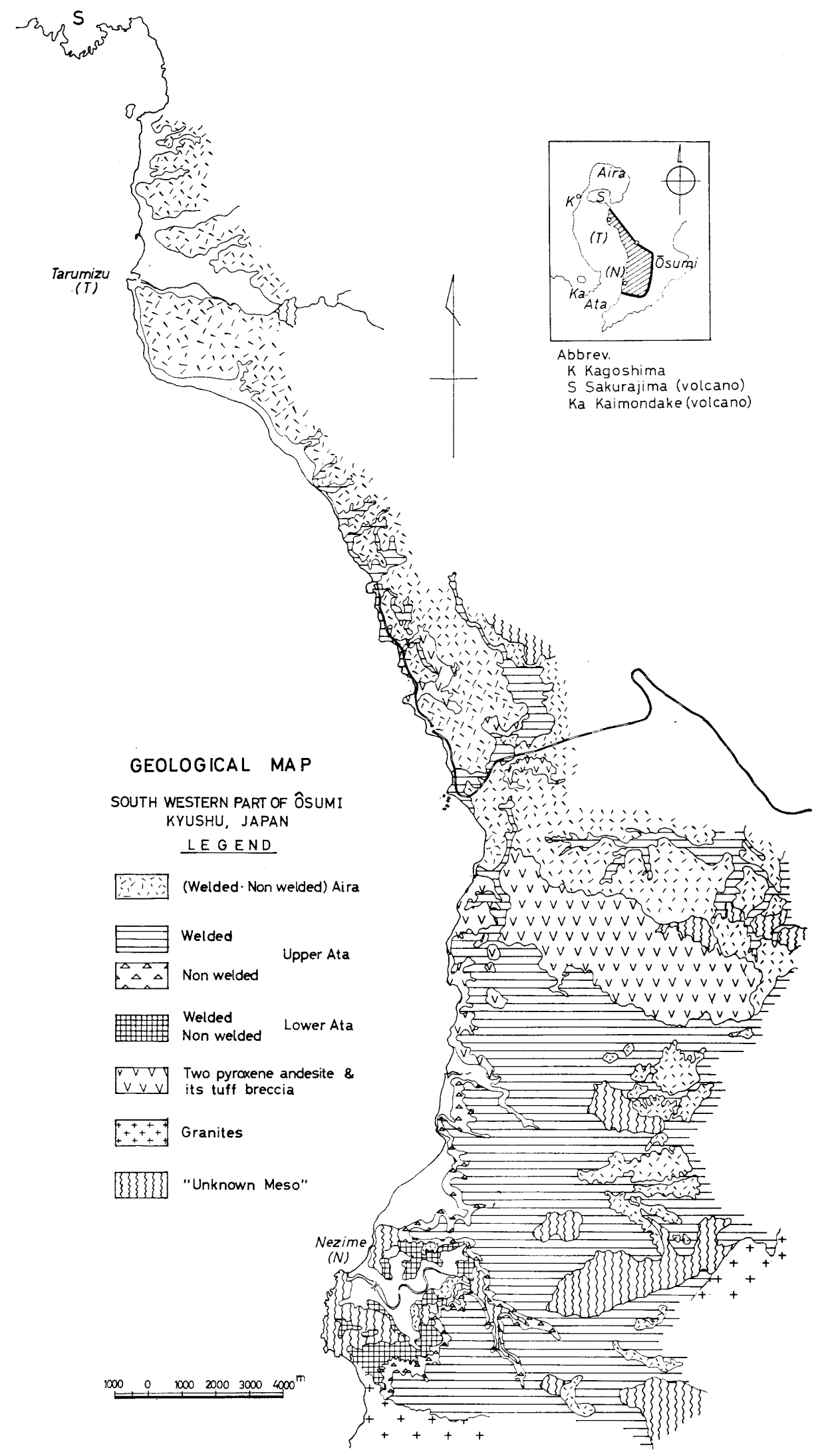

Fig. 13. Geological map of the southwestern part of Ôsumi, Kyushu, Japan. 


\section{Part VII. The "Shirasu" in the South Ôsumi district, Kagoshima Prefecture}

(Sadakatu TANEDA and Sumiharu IRISA)

\section{Outline of geology and petrography}

The outline of geology in the south osumi district is shown in Table 14 and Fig. 13. The brief descriptions on the main geologic units in this area are given as follows:

(1) The basement consist of the so-called "Unknown Mesozoic formation", the ôsumi granodiorite and andesite lava flow. The "Unknown Mesozoic formation" exposed in the area surveyed is composed mainly of sandstone, shale and their alterations. The ôsumi granodiorite is intruded discordantly into the "Unknown Mesozoic formation" in Lower-Middle Miocene. The andesitic lava flow and tuff breccia cover the formation and granodiorite just mentioned.

Table 14. Stratigraphic succession in the S. Osumi district

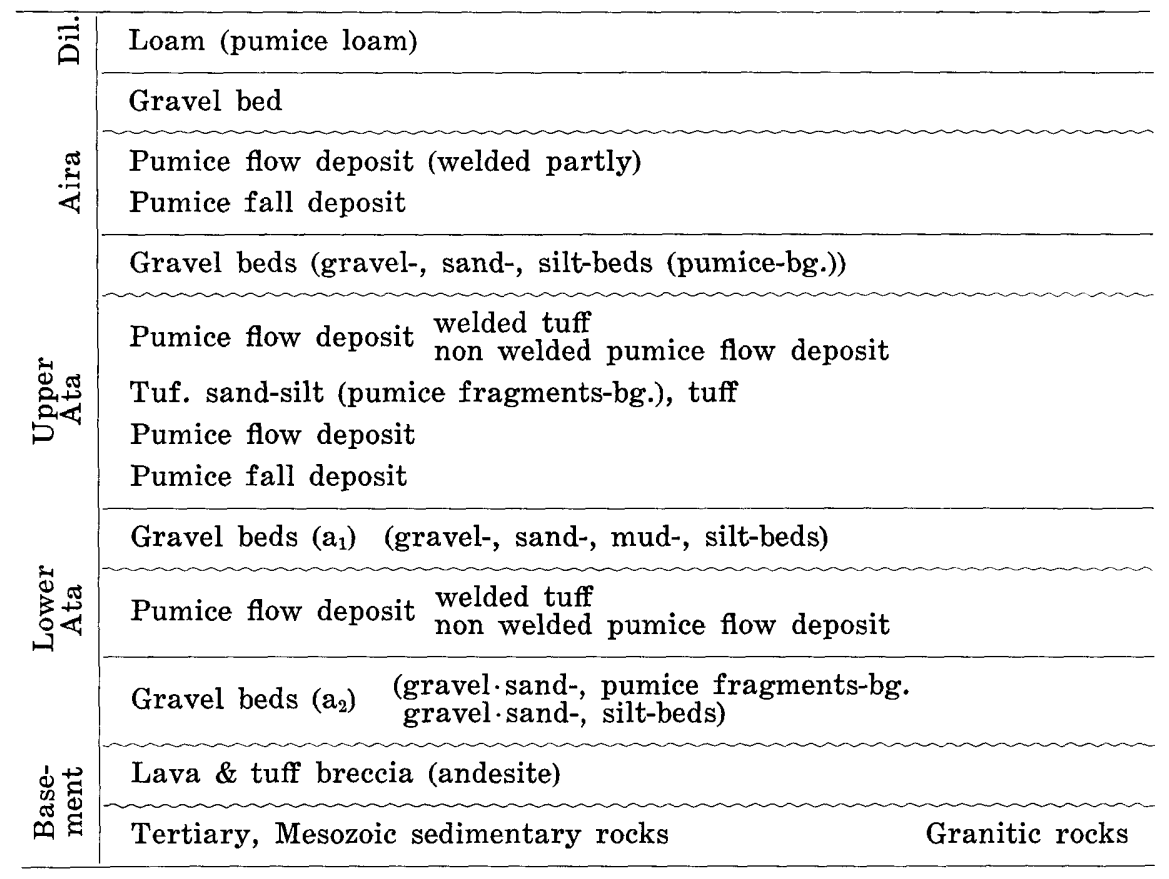

(2) The "Ata pyroclastics" are divided into two parts, the lower and the upper. The latter consists of welded to nonwelded pumice flow deposits, pumice fall deposit and subordinate tufaceous sand, and the former of welded nonwelded pumice flow deposits.

Under the microscope the pumice of the "upper Ata" contains phenocrysts of plagioclase, hornblende, hypersthene with subordinate magnetite and apatite. 
Plagioclase phenocrysts are 0.5 to $1 \mathrm{~mm}$ in length, subhedral or flaky in form, showing zonal structure. Microphenocrystic plagioclase have sometimes dusty core.

The pumice of the "lower Ata" contains plagioclase, hypersthene, augite, magnetite and apatite.

The refractive indices for the glass of the Acta pyroclastics are mostly 1.505-1.515 as shown in Fig. 14.

The chemical compositions of the pumices of the "upper Ata" from ônezime and of the "lower Ata" from Nezimo are listed in Table 15.

(3) The "Shirasu" pumice flow deposit, up to 40 meters thick, cover the Ata pyroclastic flow deposits. It is light gray to white, nonwelded and nonconsolidated, and composed mainly of pumice fragments, lithic fragments, glass flakes and a small amount of crystal grains of plagioclase, quartz, hypersthene and augite with or without hornblende.

Refractive indices for the glass are 1.496-1.502 as shown in Fig. 14.

The chemical compositions of the "Shirasu" from Nezime are shown in Table 15.

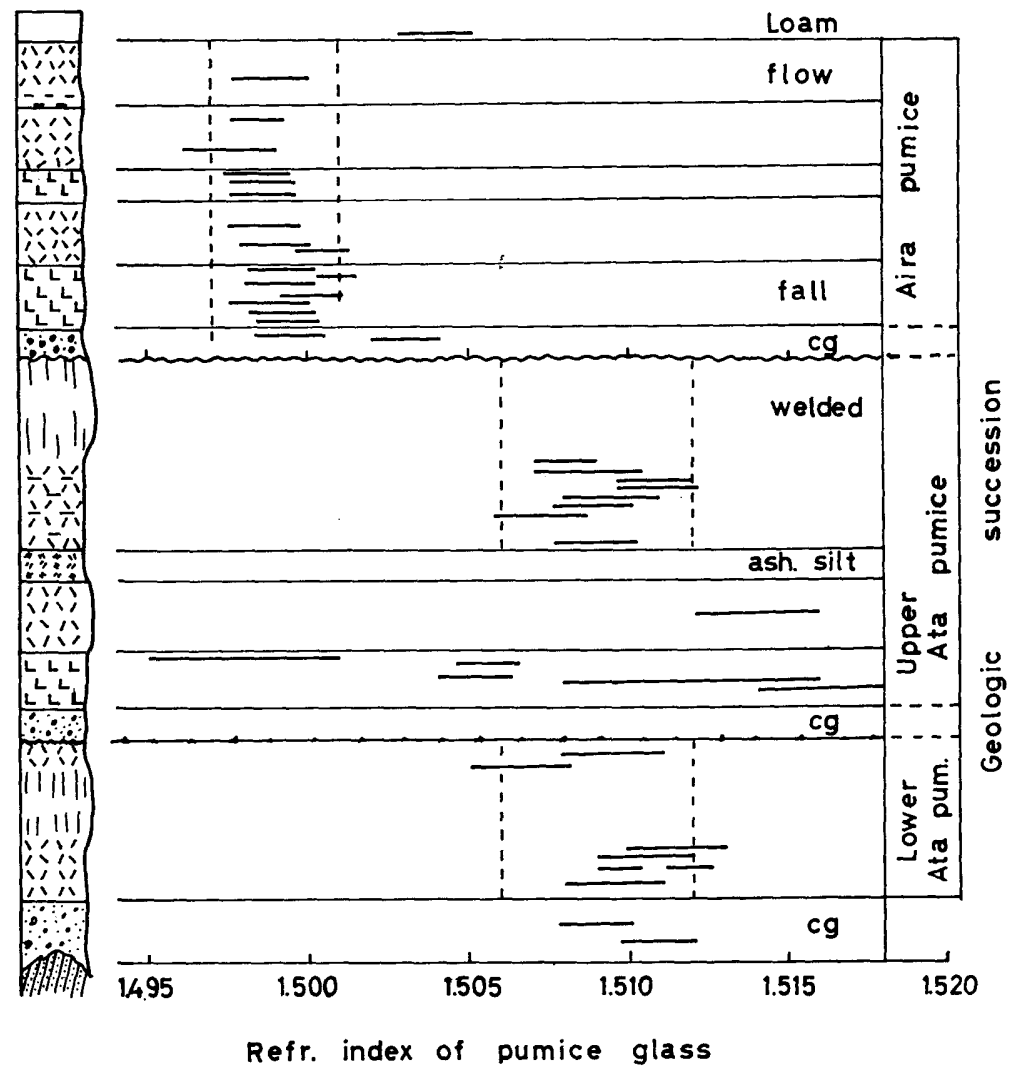

Fig. 14. Refractive index of pumice glass. 
Part VII. The "Shirasu" in the South Ôsumi district, Kagoshima Prefecture

Table 15. Chemical compositions of pumice

\begin{tabular}{|c|c|c|c|c|}
\hline & 1 & 2 & 3 & 4 \\
\hline $\mathrm{SiO}_{2}$ & 65.27 & 67.27 & 71.43 & 71.04 \\
\hline $\mathrm{TiO}_{2}$ & 0.69 & 0.68 & 0.22 & 0.26 \\
\hline $\mathrm{Al}_{2} \mathrm{O}_{3}$ & 16.30 & 15.35 & 13.97 & 13.77 \\
\hline $\mathrm{Fe}_{2} \mathrm{O}_{3}$ & 0.30 & 0.96 & 0.40 & 0.04 \\
\hline $\mathrm{FeO}$ & 2.63 & 2.17 & 1.25 & 1.24 \\
\hline $\mathrm{MnO}$ & 0.10 & 0.12 & 0.04 & 0.03 \\
\hline $\mathrm{MgO}$ & 1.19 & 1.06 & 0.53 & 0.49 \\
\hline $\mathrm{CaO}$ & 3.05 & 3.15 & 2.46 & 2.25 \\
\hline $\mathrm{Na}_{2} \mathrm{O}$ & 3.78 & 3.97 & 4.04 & 4.00 \\
\hline $\mathrm{K}_{2} \mathrm{O}$ & 2.50 & 2.50 & 3.00 & 3.05 \\
\hline $\mathrm{H}_{2} \mathrm{O}_{+}$ & 2.93 & 3.15 & 3.50 & 2.70 \\
\hline $\mathrm{H}_{2} \mathrm{O}_{-}$ & 0.26 & 0.35 & 0.36 & 0.44 \\
\hline $\mathrm{P}_{2} \mathrm{O}_{5}$ & 0.35 & 0.18 & 0.23 & 0.24 \\
\hline Total & 99.67 & 100.91 & 101.43 & 99.55 \\
\hline \multicolumn{5}{|c|}{ Anal. S. IRIS } \\
\hline glass n & 1.507 & 1.508 & 1.498 & 1.498 \\
\hline & -1.510 & -1.511 & -1.501 & -1.501 \\
\hline
\end{tabular}

1. The upper Ata pumice fall (Coll. from Siromoto, Ônezime Town)

2. The lower Ata pumice flow (Coll. from Nakahara, Nezime Town)

3. The Aira pumice fall (Coll. from Minamitani, Nezime Town)

4. The Aira pumice flow (Do.)
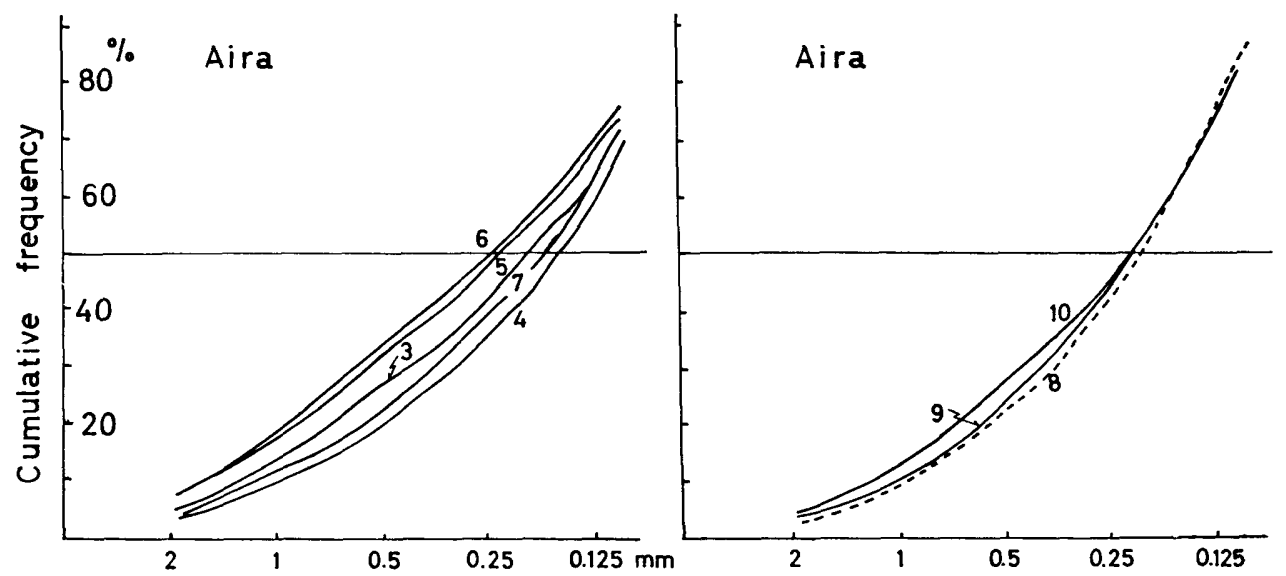

Fig. 15. Cumulative curves for the "Shirasu" (pumice flow of the Aira volcano. Nos. refer to Table 2. 


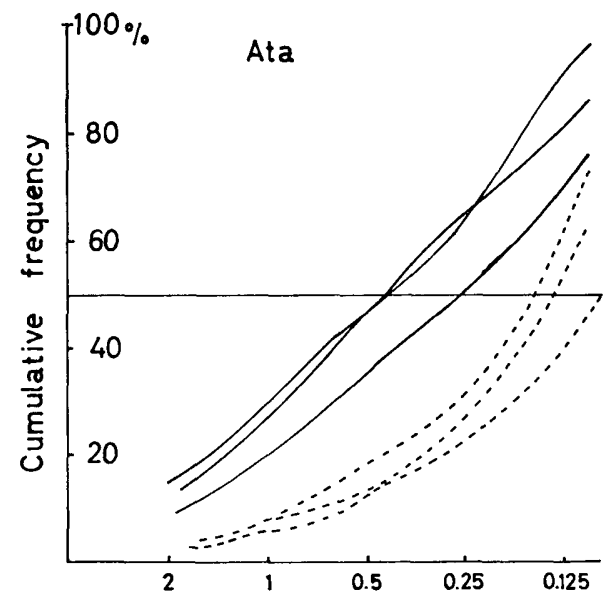

Fig. 16. Cumulative curves for the pumice flow of the Ata volcano. Full lines: for the "upper Ata" Dotted lines for the "lower Ata"

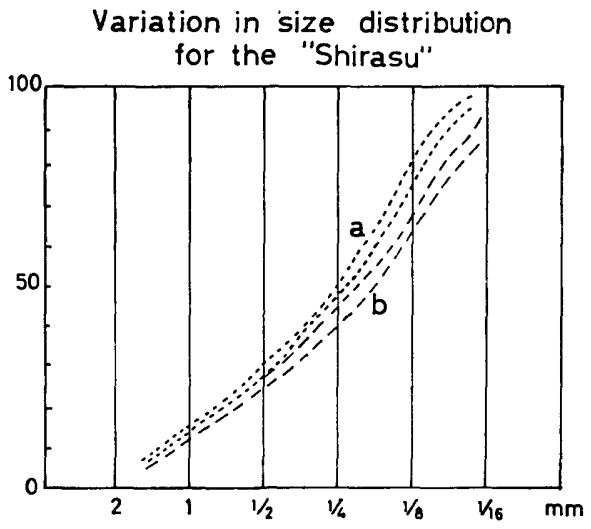

Fig. 17. Diagram showing the variation in size distribution for the "Shirasu" at Eguchiura, Higashiichiki Town, (TANEDA et al., 1957)

Table 16. Size distribution, excluding large fragment $(>4 \mathrm{~mm})$

\begin{tabular}{r|r|r|r|r|r|r|r|r|r|r}
\hline $\begin{array}{r}\text { Size } \\
\mathrm{mm}\end{array}$ & $4-2$ & $2-1$ & $1-0.5$ & $0.5-0.25$ & $\begin{array}{l}0.25- \\
0.177\end{array}$ & $\begin{array}{l}0.177- \\
0.125\end{array}$ & $\begin{array}{l}0.125- \\
0.105\end{array}$ & $0.105>$ & Total & Md \\
\hline I- 1 & 2.4 & 4.9 & 6.2 & 9.5 & 8.4 & 9.2 & 6.4 & 53.1 & 100.1 & 0.10 \\
2 & 1.9 & 3.6 & 7.8 & 13.9 & 12.7 & 14.2 & 9.7 & 36.1 & 99.9 & 0.13 \\
3 & 2.9 & 5.2 & 9.8 & 12.9 & 13.6 & 18.5 & 12.9 & 24.1 & 99.9 & 0.16 \\
II- 1 & 8.6 & 11.4 & 15.9 & 15.2 & 9.5 & 9.9 & 7.3 & 22.2 & 100.0 & 0.26 \\
2 & 12.3 & 14.5 & 19.9 & 18.6 & 9.2 & 8.2 & 4.3 & 13.0 & 100.0 & 0.45 \\
3 & 14.3 & 15.2 & 17.3 & 17.4 & 15.5 & 12.1 & 5.4 & 2.7 & 99.9 & 0.41 \\
III- 1 & 3.1 & 7.0 & 12.0 & 16.7 & 12.8 & 14.6 & 7.4 & 26.4 & 100.0 & 0.19 \\
2 & 2.6 & 6.9 & 12.6 & 18.9 & 13.4 & 16.5 & 10.1 & 18.9 & 99.9 & 0.20 \\
3 & 3.7 & 6.4 & 12.0 & 16.6 & 11.9 & 13.8 & 7.3 & 28.3 & 100.0 & 0.18 \\
4 & 3.1 & 6.2 & 11.3 & 14.5 & 10.8 & 14.1 & 10.4 & 29.6 & 100.0 & 0.16 \\
5 & 6.5 & 10.8 & 15.0 & 15.6 & 10.0 & 10.9 & 5.2 & 26.0 & 100.0 & 0.26 \\
6 & 6.6 & 11.7 & 15.9 & 15.7 & 9.1 & 11.0 & 5.9 & 24.0 & 99.9 & 0.30 \\
7 & 4.5 & 8.7 & 13.4 & 15.1 & 10.7 & 11.9 & 8.1 & 27.7 & 100.1 & 0.19 \\
8 & 3.0 & 6.7 & 13.1 & 19.5 & 14.9 & 17.3 & 10.5 & 14.8 & 99.8 & 0.20 \\
9 & 3.2 & 7.6 & 13.3 & 19.6 & 14.5 & 16.1 & 9.2 & 16.4 & 99.9 & 0.21 \\
10 & 4.5 & 8.2 & 14.0 & 18.3 & 12.5 & 14.3 & 7.0 & 21.1 & 99.9 & 0.22 \\
11 & 3.7 & 7.3 & 12.4 & 17.1 & 12.6 & 18.3 & 7.4 & 21.3 & 100.1 & 0.19 \\
12 & 4.9 & 10.1 & 14.9 & 18.6 & 12.5 & 13.4 & 7.8 & 17.9 & 100.1 & 0.27 \\
\hline
\end{tabular}

I. Lower "Ata" pumice flow from Nezime $T$.

II. Upper "Ata" pumice flow from Nezime T.

III. "Aira" pumice flow

Localities: 1 Kamigawa, Nezime T. 2 Minamitani, Nezime T. 3 Nukumi, Nezime T. 4 Hamada, Nezime T. 5 Furue, Tarumizu C. 6 Terada, Tarumizu C. 7 Arahira, Kanoya C. 8 Nakagori, Tasiro V. 9 Sirai, Nezime T. 10 Tomano, Aira T. 11 Nisinome, Aira T. 12 Sisinome, Kanoya C.

(C City, T Town, V Village) 


\section{Size distribution}

The samples of the "Shirasu" from twelve localities was analysed mechanically with sieves. The results are shown in Table 16, and illustrated in Fig. 15. The size distribution for the "Shirasu" in this area also shows the characteristic of the pumice flow deposit. It is, however, to be noted that the "Shirasu" from the high level plateau region is slightly well sorted compared with the "Shirasu" from the coastal plain. As to the latter the median diameter ( $M d$ ) decreases with increase of the distance from the center of the Aira caldera (Fig. 15).

The "lower Ata" is smaller than the "upper Ata" in median diameter (Md) (Table 16, Fig. 16).

\section{Remarks}

In the south ôsumi district, where is the southern end of the "Shirasu Region", are developed the pyroclastic flow deposits erupted from the different eruptive sources. One of them is the Ata pyroclastic flow deposits erupted from the Ata caldera volcano. Another is the "Shirasu" erupted from the Aira caldera volcano.

The "Shirasu" is light gray to white pumice flow deposits, and composed mainly of pumice and lithic fragments, glass flakes and a small amount of crystal grains of plagioclase, quartz, hypersthene and augite with or without hornblende.

The Size distribution for the "Shirasu" in this area also shows a characteristic of a pumice flow deposit. Generally speaking, the relation between median diameter (Md) and the distance from the center of the Aira caldera is not always regular, but as to the "Shirasu" of coastal plain it is found that Md decreases with increase of the distance.

\section{Appendix: Preliminary note on the pyroclastic flow magma}

It is one of the most interest problems, how to generate the acid magma to produce the pyroclastic flow substance. As to this problem it is important that the Aira and Ata pumices resemble the Takakuma and ôsumi granitic rocks (ÔBA, 1963; TANEDA et al., 1966) respectively in some chemical characteristics as shown in Figs. 18 and 19. It seems to be suggestive to derive a conclusion that the acid pumice flow magmas are intimately related to the granitic rocks constructing the basement of the caldera volcano, from which the pumice flow pumice was ejected (TANADA and IRISA, 1966). 


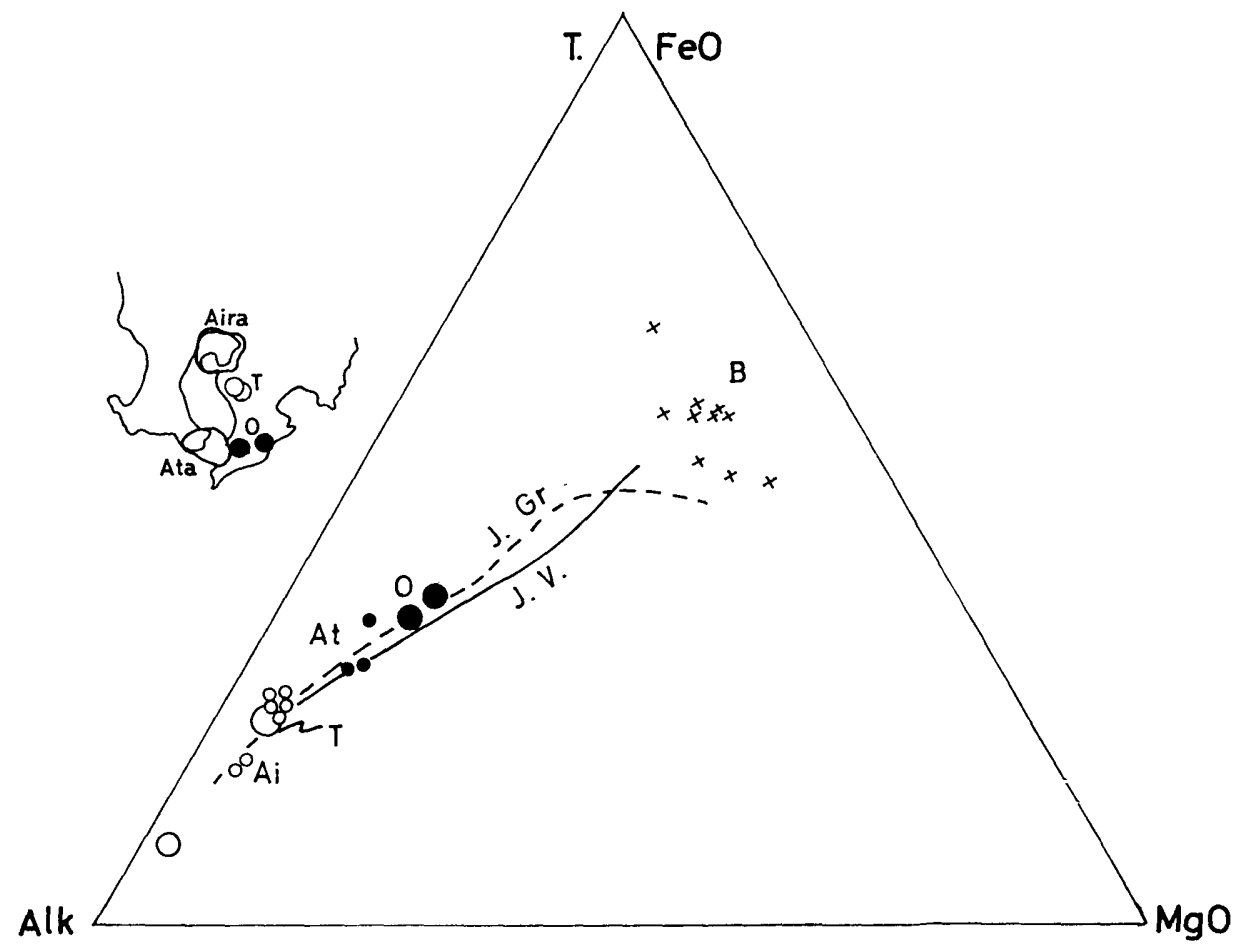

Fig. 18. $\mathrm{T} \cdot \mathrm{FeO}-\mathrm{MgO}-\mathrm{Alk}$ relations of the Aira pumice (Ai), the Ata pumice (At), the Takakuma granites $(\mathrm{T})$ and the Ôsumi granodiorites $(0)$.

B: Basalts from the peripheral district of the Aira caldera (YAMAGUCHI, K., 1934)

J.Gr: Japanese granitic rocks average (TANEDA, 1962)

J.V.: Japanese volcanic rocks average (Do.)

T,O : Oba, 1931. Ai: Yamaguchi, 1938; TANEdA et al., 1966. At: Taneda et al., 1966.

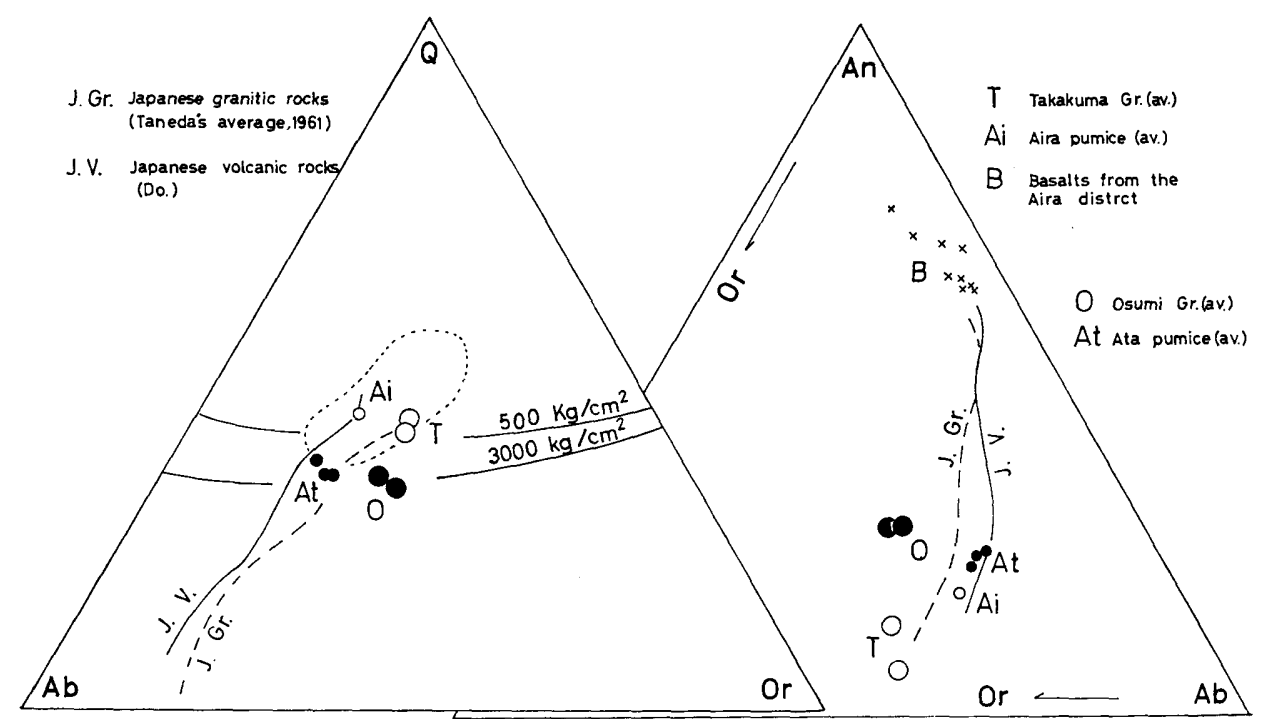

Fig. 19. The normative $\mathrm{An}-\mathrm{Ab}-\mathrm{Or}$ and $\mathrm{Q}-\mathrm{Ab}-\mathrm{Or}$ relations.

Abbrev. refer to Fig. 18. 


\section{References}

EGUCHI, M. (1942): Fossil corals from the Torinosu limestone of Yamagami, Nishikaseda-mura, Kawanabe-gun, Kagoshima-ken. Jour. Geol. Soc. Japan, 49, (583), 143-147.

Matsumoto, T. (1943): The four gigantic caldera volcanoes of Kyushu. Jap. Jour. Geol. Geogr., 19 (special number), 1-57.

Mryachi, M. (1963) : Petrological study of the Shirasu in Southern Kyushu, Japan. I. Some petrographical notes. Rept. Earth Sci., Dept. General Edu., Kyushu Univ., (10), 55-60.

(1964): Petrological study of the Shirasu in Southern Kyushu, Japan. II. Quartz, plagioclase feldspar. Sci. Rep. Fac. Sci., Kyushu Univ., Geol., 7, (1), $11-16$.

(1965): Pyroclastic sediments of the Takaharu area, Miyazaki Prefecture. Rept. Earth Sci., Dept. General Edu., Kyushu Univ., (12), 21-31.

and MiYachi Sadanori (1965): Petrological study of the Shirasu in southern Kyushu, Japan. III. Accessory zircon. Rept. Earth Sci., Dept. General Edu., Kyushu Univ., (12), 11-20.

(1966): Pyroclastic sediments of the Hitoyoshi Basin, Kumamoto P'refecture. Rept. Earth Sci., Dept. General Edu., Kyushu Univ., (13), 25-33.

(1967): Petrological study of the Shirasu in Southern Kyushu, Japan. Rept. Earth Sci., Dept. General Edu., Kyushu Univ., (14), 15-55.

NARUSE, Y. (1966): The Quaternary tephras to the east of Kirishima volcano. Misc. Rep. Res. Inst. for Nat. Resources, (66), 15-33.

ÔBA, N. (1963) : Chemical composition of the Kyushu outer zone granitic rocks. Sci. Rep., Kagoshima Univ., (12), 35-51.

ONo, K. (1965): Geology of the Eastern Part of Aso Caldera, Central Kyushu, Southwest Japan. Jour. Geol. Soc. Japan, 71, (842), 541-553.

Sawamura, K. (1956): Kokubu, Explanatory text of geological map of Japan. Geol. Surv. Japan. 1-19.

and MATSUi, Kazumori (1957): Kirishimayama, Explanatory text of geological map of Japan. Geol. Surv. Japan. 1-58.

Tamura, M., Y. Tokuyama, and K. Tanoue (1962): Geology of the western part of Hitoyoshi Basin, Kumamoto Prefecture. Mem. Fac. Educ. Kumamoto Univ., 10, $49-56$.

TANEDA, S. (1954): Geological and petrological studies on the "Shirasu" in South Kyushu, Japan. P'art I. Preliminary Note. Mem. Fac. Sci., Kyushu Univ., Geol., 4, (2), 167-177.

(1957): Geological and petrological studies of the "Shirasu" in South Kyushu Japan. Part II. Preliminary Note (2). Mem. Fac. Sci., Kyushu Univ., Geol., 6. (2), 91-105.

, S. MiYACHI, and M. Nishinara (1957): Geological and petrological studies of the "Shirasu" in South Kyushu, Japan. Part III. Mem. Fac. Sci., Kyushu Univ., Geol., 6, (2), 107-127.

(1962): Chemical compositions of granitic and volcanic rocks in Japan. Jour. Geol. Soc. Japan, 68, 118-124.

(1963) : Some properties of pumice flow covering the east side of Kirishima Volcano. Bull. Volc. Soc. Japan [2], 8, (1), 43-44.

and S. IRISA (1966): Pyroclastics of South Ōsumi district. Sci. Rep. Shimabara Inst. Volcanology \& Balneology, Fac. Sci., Kyushu Univ., (2), 11-21.

(1968): Geological studies on the damage of the "Ebino earthquake" in 1968. Bull. Volc. Soc. Japan, [2], 10, (2), 62-73.

YamaGUCHI, K. (1934): Studies on the basalt around Bay of Kagoshima. Jour. Geol. Soc. Japan, 41, 390-392.

(1938): Petrological study of the pumice around the Bay of Kagoshima (pt. 3). Jour. Geol. Soc. Japan, 45, 782-790. 